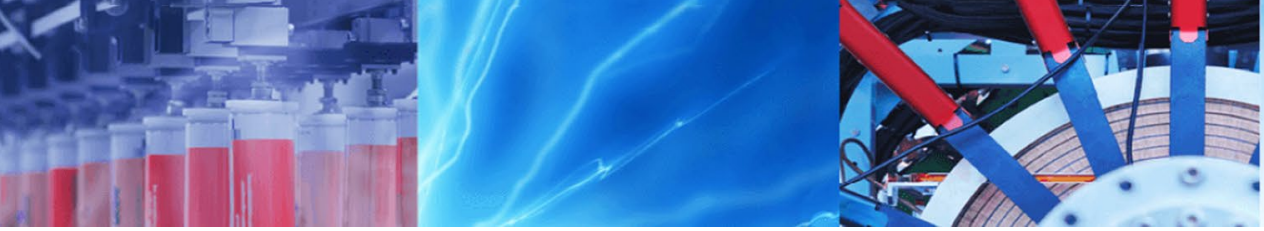

Research Article

\title{
A sustainability study of the flow regulation impacts by dams in a carp breeding river using the hydrodynamic model and building block analysis
}

\author{
Probal Saha $^{1}$ (I) $\cdot$ Minhazul Islam $^{2} \cdot$ Jarin Tasneem Oyshi ${ }^{1} \cdot$ Roufa Khanum $^{1} \cdot$ Ainun Nishat $^{1}$
}

C Springer Nature Switzerland AG 2019

\begin{abstract}
Halda, one of the major tributaries of the mountainous river Karnaphuli, is well known as the country's only natural carp spawning ground. Naturally fertilized eggs of carps collected from Halda River are hatched in mud-made scoops on the river bank for aquaculture purposes. However, the river habitat is under constant threat due to human interventions like loop cutting, pollution from the paper mill and power plant, blocking natural water flow of larger tributaries by introducing sluice gates, embankments and rubber dam over the river at upstream, as well natural causes like siltation, erosion and climate change impacts. A study is conducted to address the issues of the ecosystem, sustainable management and the flow regulation impacts of dams in the Halda River, although the flow regulation assessments are conducted based on the macroinvertebrate, index-based framework, land-use effects on the hydrology, new indicators development, hydrologic impact assessment, hydrodynamics in dam regulated rivers, surface-water hydrodynamics and regimes of a small mountain stream and wide range of initiatives. In our case, we considered runoff flow, mountainous flow and dams in the rivers are primary parameters for assessment, so based on previous studies we decided to simulate a hydrologic and hydrodynamic model for the dam and without dam scenarios. Major difficulties and challenges for the environmental flow analysis of a river are continuous data availability. In this research, a hydrologic model ArcSWAT has been built to assess the contribution of rainfall on the river discharge to be used as output from the tributaries in the hydrodynamic model Delft3D. The research findings help us to perceive the effect of the dams on fish breeding condition in the river. In order to perform the environment flow analysis of the river, Tennant method has been followed in the study, which is a secure and reliable approach. The flow regulation impacts are assessed for fish habitat and spawning in the river area based on the simulations. Finally, the findings are further analyzed for velocity profiles for dams by building block method for the sustainable aquatic habitat in the Halda River.
\end{abstract}

Keywords Halda River · Flow regulation · Delft3D · Dam impacts · Fish habitat · Sustainable management

\section{Introduction}

Halda is one of the major tributaries of the tidal and mountainous river Karnaphuli which is well known as the country's only natural spawning ground of major carps. It originates from the Badnatali Hills range in Ramgarh Upazila in the Chittagong Hill Tracts and flows into the
Karnaphuli River at about $35 \mathrm{~km}$ from the Bay of Bengal. The significant sources of flow in the Halda River are 19 branch canals and 17 hilly fountains [1]. The fish breeding places along the river are locally known as "Koom." Local people collect carp fish eggs from these places and hatch them to produce the carp fries [2]. Naturally fertilized eggs of carps are collected from Halda River and

\footnotetext{
$\triangle$ Probal Saha, probal1421@gmail.com; Minhazul Islam, mislam48@students.tntech.edu; Jarin Tasneem Oyshi, jtoyshi@bracu.ac.bd; Roufa Khanum, roufa@bracu.ac.bd; Ainun Nishat, nishat@bracu.ac.bd| ${ }^{1}$ Centre for Climate Change and Environmental Research (C3ER), BRAC University, Dhaka 1212, Bangladesh. ${ }^{2}$ Civil and Environmental Engineering, Tennessee Technological University, Cookeville, TN 38501 , USA.
}

SN Applied Sciences (2019) 1:1429| https://doi.org/10.1007/s42452-019-1417-0

Received: 11 January 2019 / Accepted: 9 October 2019 / Published online: 17 October 2019 
hatched in mud-made scoops on the river bank for the aquaculture purposes [3]. However, the recent hydrological changes in monsoon floods are triggering the radical degradation of spawning in the Halda River.

The responsible factors behind the degradation are an abrupt rise in water level (WL) due to the monsoon floods, increasing current velocity and turbidity, decreasing water temperature, dissolved oxygen (DO) and conductivity, and slight acidic nature of water. The interaction of all these factors provides a unique hydrological condition at the spawning ground which might stimulate the triggering of carp spawning in the Halda River [4]. The river habitat is under extinction threat due to loop cutting in meanders, sand mining, blockage of flow by dams, sluice gates, embankments, pollution from paper mills, power plants, rubber dams over the river at upstream. Natural causes like siltation, erosion, climate change impacts are also influencing the changes in the river ecosystem [5]. Moreover, increased salinity in the Halda River has already posed a serious threat to city water supply over three dry seasons [6]. More than 30,000 ha of croplands on both the riverbanks in the downstream area is facing a severe threat of soil degradation due to high salinity [6]. During the dry season, approximately 8-13.5 Crore liter of water needs to be withdrawn by Bhujpur rubber dam and 3.3-5.5 Crore liter of water is withdrawn by Haruwalchhari rubber dam for cultivating Boro rice and irrigation of tea garden [2]. This withdrawal is not only disturbing the aquatic life but also cause side effects such as bank erosion and saline intrusion. The brickfields are precisely at the edge of the river, which means dumping of their waste and debris into the river by default during the hide tide, which does not dissolve in the water and causes severe sedimentation, along with changing the chemical balance of the river water [7]. According to [8], the Halda River is being polluted due to industrial waste $(53 \%)$, sewage contamination (20\%), tobacco farming (13\%), a rubber dam (8\%) and sand extraction (6\%). Sand mining is another significant issue which is damaging the river ecosystem, whereas the dams are helping the deterioration process [2]. According to [9], water transport is also another concern for river Halda as due to dams and sluice gates the downstream sections are often dried up, and navigation becomes hard through the river. All in all, total tangible resources of Halda River calculated by is about 20.5 million US\$ which has a massive influence on the country's economy.

Through the facts above, it is clear that river Halda is losing its resources and sustainability day by day. The proper study, innovative approaches and sustainable actions of the resources will only help for the revival of the river. Therefore, essential preventive measures must be taken to control the unwise and unauthorized discharge of harmful pollutants into the River for the better management and conservation of natural resources.

There is a wide range of initiatives and parameters to conduct the flow regulation impact assessments depending on the location and conveniences. The assessments were conducted based on using macroinvertebrate information from mesohabitats [10], index-based framework for patterns and trends [11], analysis of managed versus unmanaged scenarios [12], land-use effects on the hydrology [13], new indicators development to evaluate river fragmentation [14], hydrologic impact assessment [15], sediment dynamics and hydrodynamics in dam regulated rivers [16], surface-water hydrodynamics and regimes of a small mountain stream-lake ecosystem [17]. In our case, we considered runoff flow, mountainous flow and dams in the rivers are primary parameters for assessment, so based on past studies we decided to conduct a hydrologic and hydrodynamic assessment. The hydrologic assessment will give a detailed analysis of the rainfall-runoff impact on the river, and the hydrodynamic model will assess the mountainous topography and dam impacts on the river flow for our flow regulation impact assessment.

Major difficulties and challenges for the environmental flow analysis of a river are continuous data availability. In order to perform environmental flow analysis, sufficient amount of discharge data, ecological data and other information is needed which are very hard to figure out in such conditions. In this research, instead of relying on only field data availability, a hydrologic model (ArcSWAT) has been built to assess the actual field condition through some calibration and validation of the model. SWAT model has been used to analyze the contribution of rainfall on the river discharge. Then, the discharge output from the tributaries has been used in the hydrodynamic model, Delft3D, to figure out the river water-level changes. Using this hydrodynamic and hydrologic model incorporation, river discharge condition and water-level condition have been simulated. The research findings help us to perceive the effect of the dams on fish breeding condition in the river. In order to analyze the fish breeding condition or to perform the environment flow analysis, Tennant method has been followed in the study. This methodology is a secure and reliable approach to figure out the environmental flow condition of any river.

There are extensive variety methods which have been developed in the article [18], wherein a total of 207 significantly different EFA methods implemented in 44 countries within six regions of the world [19]. However, four different models have been listed down from various research articles [19-23].

Hydrologic index models are inexpensive and straightforward-Tenant (Montana) method, U.S. Fish and Wildlife Service (1976), Lyons Method, Texas Parks and Wildlife 
Department (1979), Biological Flows, IHA, The Nature Conservancy (1997) and the range of variability approach (RVA) [24] and Hydrological Assessment Tool (HAT) [25]. Hydraulic models are used to compute and correlate available habitat areas based on river channel geometry. Examples include-Wetted perimeter method, Montana Department of Fish, Wildlife, and Parks, the 1970s and R2-Cross method, Colorado Division of Wildlife, 1980s. Habitat models are generally complicated and data intensive and use target species population data with hydraulic data to determine optimal habitats. An example is Instream Flow Incremental Methodology (IFIM), U.S. Fish and Wildlife Service, the 1970s, which includes the Physical Habitat Simulation Model (PHABSIM) [26, 27]. Holistic models are generally very complex and data intensive and are based on multidisciplinary scientific consensus. Examples include-Building Block Methodology (BBM), South Africa Department of Water Affairs and Forestry and the University of Cape Town, 1990s [28]; Downstream Response to Imposed Flow Transformation (DRIFT), South Africa Department of Water Affairs and Forestry, the University of Cape Town, and Southern Waters Ecological Research and Consulting, 1990; Catchment Abstraction Management Strategies (CAMS; Environment Agency 2010) and Expert panel or consensus, such as the Nature Conservancy's Collaborative and Adaptive Process for developing environmental flow recommendations [29].

Among the methods stated above, hydrologic model index method has been used in the study. This discharge datum is used to figure out the percentage of flow through the river reach, which is compared later with the index values from the Tennant method. It helps to know the average flow of the river throughout the year and to figure out the changes in the river environmental flow condition.

To assess the overall flow degradation scenario and sustainability of the aquatic habitat, it was essential to study Halda River using the hydrodynamic modeling and building block analysis which will be instrumental in future policy formulation and sustainable implementation.

\section{Study area}

The sustainability study of the flow regulation is focused on the impacts on the carp breeding river due to obstruction in dams. In Bangladesh, Halda is the only natural carp breeding river among the 57 rivers [30]. Moreover, the Halda River is to be declared as the Ecologically Critical Area in Bangladesh to protect the sanctuary of the carp fishes [31]. So, a study on the Halda River will be ideal to understand the impacts on the carp breeding fishes of a flow-threatened river and will give an impression about one of the most critically endangered scenarios.
A reach of almost $88 \mathrm{~km}$ along the Halda River is selected as the study area for the hydrodynamic Delft3D model. The study is developed using the data collected from the Bangladesh Water Development Board (S) and data generated from the ArcSWAT hydrologic model. The upstream boundary is selected at Manikchhari, and the downstream boundary is selected at Enayethat. Initially, a historical trend analysis is conducted for available datariver flow, water level, velocity, rainfall and topography data. Although for the hydrological simulation, the data are selected for the years 2000-2015 to generate stream discharges from all outlets. The most recent and updated data available for hydrodynamic simulation-boundary data and calibration and validation data, are the year 2014 . Moreover, the hydrological model was also calibrated for the year 2014 for the usage of stream discharges at all outlets in the hydrodynamic model. However, a more recent data of 2015 or 2016 would have been more preferable if had been available, but the result would have been similar for Halda River as the flow degradation scenario is an accumulation of the impacts of long past years. Finally, the model is calibrated and validated for the year 2014 at Narayanhat and Telpari stations (Fig. 1).

\section{Methodology}

Nowadays, conventional artificial intelligence and computational intelligence methods are practical to an early flood warning, which is essential for effective response in flow scenarios [32]. Accurately, hydrological simulation remains a challenging task despite the fact that a wide range of modeling techniques, artificial neural network (ANN)-based rainfall-runoff models, has received considerable attention in hydrology community owing to their capability to reproduce the highly nonlinear nature of the relationship between hydrological variables [33]. Besides, river flow forecasting is an essential task for water resources management, water demand assessments, irrigation, which are vital to our river flow study [34]. Previous literature has suggested that higher predictions of total streamflow can be obtained via standard artificial neural networks (ANNs) trained to perform the associated implicit baseflow separation. These modular models fit separately the baseflow and excess flow components as produced by a digital filter and reconstruct the total flow by adding these two signals at the output [35]. Accurate simulation of evaporation plays a vital role in the efficient management of water resources [36]. Evaporation accounts for variable shares of water balance below completely different atmospheric conditions, and its correct prediction poses a significant challenge before water resources management in watersheds [37]. In our case, the integration of 


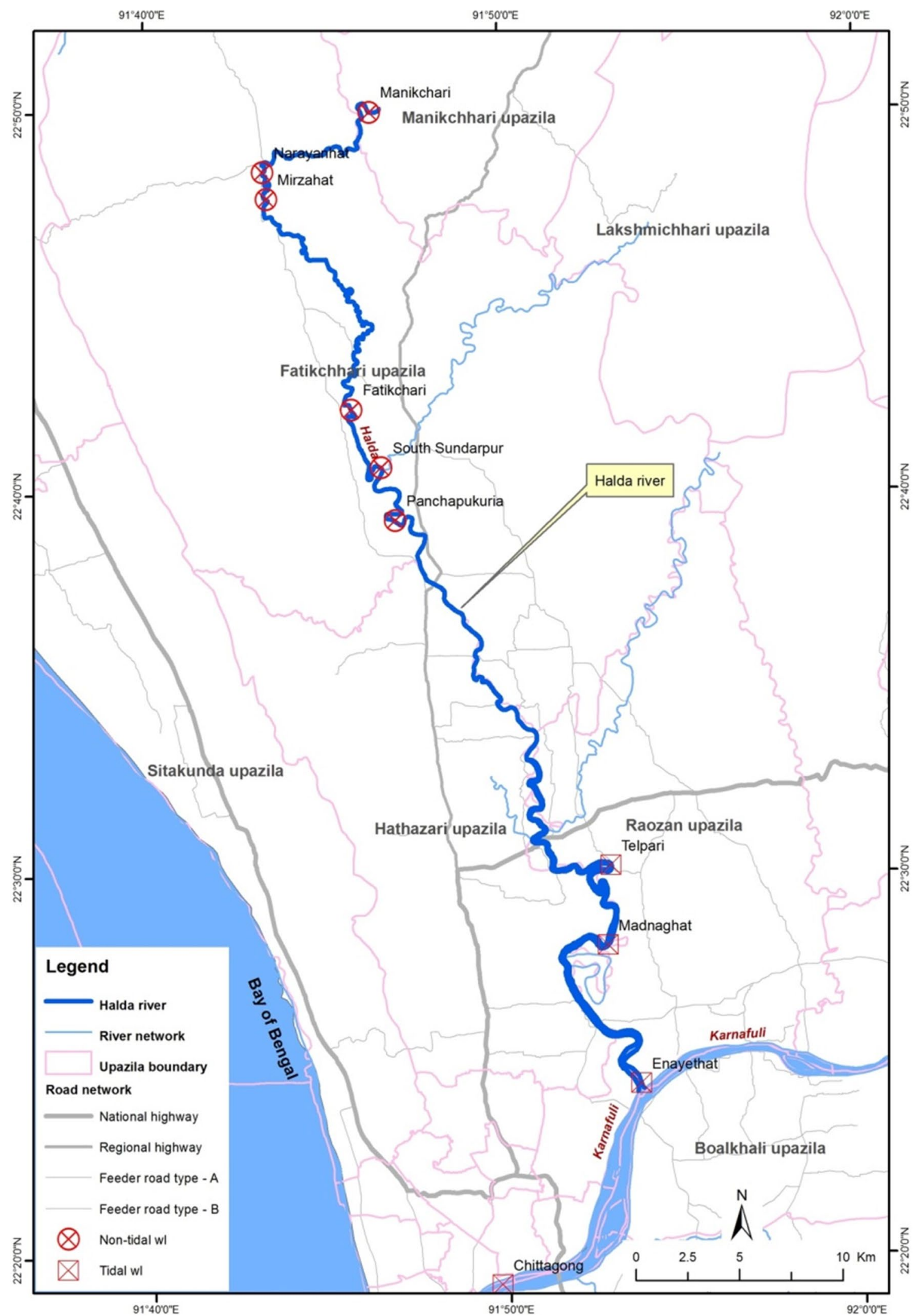

Fig. 1 Halda River system of Bangladesh along with the tidal gauge stations 
hydrological and hydrodynamic model is established for the flow regulation assessment of the Halda River. Moreover, the results are analyzed further for the sustainability of the habitat.

\subsection{Hydrological modeling using ArcSWAT}

There are several types of hydrologic models which are HEC-HMS, AnnAGNPS, Hydrologic Simulation ProgramFortran (HSPF), SWAT, etc. Among these models, SWAT has been adopted because of its simplicity of inputting data, direct integration with ArcGIS, calibration being easy in SWAT, technical errors, user support, etc. ArcSWAT is directly integrated with the ArcGIS interface. Using ArcSWAT is less erroneous because the modeler does not need to do the watershed analysis separately in ArcGIS and manually put the watershed information in the SWAT model outside. This model is capable of inputting the data directly from the ArcGIS interface. This model has a very good user interface where the user can easily input the geological data as digital elevation model (DEM) and analyze the watershed extent as well as the stream network. Again, these watershed parameters such as watershed area, time of concentration, stream length, lag time and other hydrologic properties are calculated automatically within the model interface. So, the user does not need to calculate these parameters separately and input the data in the model. The user needs rainfall, elevation, land cover, soil data to build the uncalibrated model. After building the model, the actual discharge data are needed to calibrate the model correctly. Within the user interface, there is an available tab for the manual calibration which has been adopted in this study.

Halda River basin area is selected through the processes of digitization of the river and the surrounding reaches along with the delineation of the watershed and flow stream. The whole process will be simulated in ArcGIS and ArcSWAT. ArcSWAT is selected to build up the hydrologic model, and the delineated watershed will be used as the boundary area. Proper land cover and harmonized soil map will be used to assign the hydrologic response unit (HRU) to the catchment. Also, meteorological data (rainfall) from the Bangladesh Meteorological Department (BMD) will be used as input weather station data in the model. The rainfall-runoff from the canal stream will also be incorporated into the hydrodynamic model.

\subsubsection{Data collection}

A 30-m Shuttle Radar Topography Mission (SRTM) digital elevation model (DEM) incorporating the Halda River will be utilized for the hydrological processes. Topographic field survey and 90-m resolution DEM are other alternatives for the SRTM DEM. Except for using remote sensing data, field surveyed data can also be used for the watershed study. However, at the time of the study, field surveyed elevation data were not found and it was not feasible to collect elevation data for the whole region around river Halda. This is why SRTM 30-m DEM has been used to figure out the watershed extent and other hydrologic parameters quickly through GIS techniques. As SRTM 30-m resolution digital elevation model (DEM) is the most available high-resolution dataset for the hydrologic analysis of river Halda watershed. Otherwise, doing a topographic field survey for the study will be costlier and time-consuming concerning the scope of the study. Though it is the most available high-resolution dataset, it is still very coarse data. This dataset can pick the elevation information at an interval of the 30-m resolution, so it does not have elevation information for the points which are within 30-m interval. In order to resolve the issue in the hydrologic analysis, the 30-m resolution SRTM DEM has been reconditioned using the river shapefile to avoid streamline error for the analysis.

Besides, hydrologic response unit data were calculated using land cover and soil data. It is used to determine the variability of the soil texture, forest, urban areas, water bodies, cropland locations within the catchment boundary. Using these characteristics of the land area, curve number, soil water availability, and roughness are calculated in the model. While estimating the rainfall-runoff, this land-cover variance is utilized in the model. Input rainfall data in millimeter $(\mathrm{mm})$ are being used in the model (Table 1; Fig. 2).

Table 1 Description of the datasets used for hydrological model

\begin{tabular}{llll}
\hline Data & Source & Extent & Resolution \\
\hline Digital elevation model (DEM) & USGS Earth explorer (2015) & Global grid & $30 \mathrm{~m} \times 30 \mathrm{~m}$ \\
Natural streams of Halda River & Google Earth & Canals connected to river stream & Variable \\
Land cover and soil data & $\begin{array}{l}\text { Food and Agriculture Organization } \\
(2015)\end{array}$ & Halda River surrounding area & Variable \\
Meteorological data (rainfall) & Bangladesh Water Development & Halda River surrounding area & Variable \\
& Board (2000-2015) & & \\
\hline
\end{tabular}



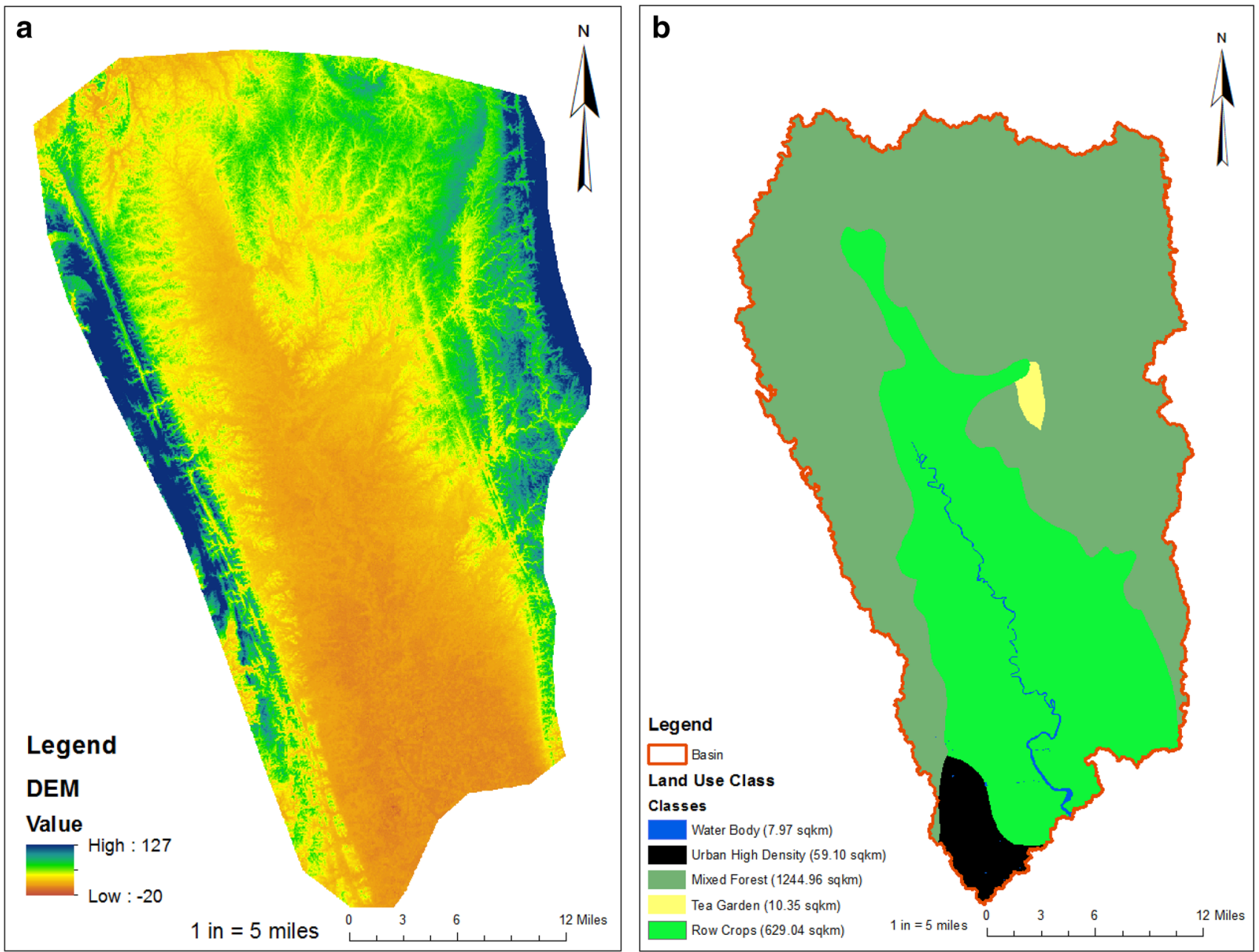

Fig. 2 a SRTM DEM and b land-cover data

\subsubsection{Basin area identification}

To ensure the rainfall-runoff without any logging within the catchment, the digital elevation model (DEM) is processed. This process is done in ArcGIS. Unusual depressions within the DEM are identified and filled by ArcGIS command sink and fill. Moreover, digitized natural stream from Google Earth image of the year 2015 is used to process the DEM. This step is essential to get the actual existing stream in the delineated watershed. Then, the final processed DEM is used to perform the flow direction and flow accumulation process where ArcGIS and ArcSWAT are used. The delineated stream direction was assigned through these flow direction and accumulation processes. After performing the flow accumulation and flow direction, stream with the outlet points is generated in ArcSWAT. Using the outlet points and stream shapefile, a watershed boundary was created

in ArcSWAT. Each outlet point has its catchment and provides the outflow from the catchment through the streamline (Table 2; Fig. 3).

\subsubsection{ArcSWAT model data input}

Land cover and soil data are imported into the model classifying them into several categories. Waterbody, urban high density, mixed forest, tea garden, and cropland are the classes used in land-cover classification. Three types of soil were identified in the catchment area. According to the Food and Agriculture Organization (FAO) soil code, Bd61-2c-3665, Af46-1-2a-3636, Ge512a-3707 are used in the soil data input. Also, rainfall data from 2000 to 2015 are used in the model. A ".txt" file for the latitude, longitude and elevation of the rainfall station were also created for the model. 
Table 2 Outlet points generated according to the observation points

\begin{tabular}{llll}
\hline No. & Observation points & Latitude & Longitude \\
\hline 1 & $\begin{array}{c}\text { Halda River Start (Manikch- } \\
\text { hari) }\end{array}$ & $22^{\circ} 50^{\prime} 6.65^{\prime \prime} \mathrm{N}$ & $91^{\circ} 46^{\prime} 25.66^{\prime \prime} \mathrm{E}$ \\
2 & Gazaria Canal & $22^{\circ} 48^{\prime} 41.78^{\prime \prime} \mathrm{N}$ & $91^{\circ} 43^{\prime} 7.43^{\prime \prime} \mathrm{E}$ \\
3 & Bhujpur rubber dam & $22^{\circ} 45^{\prime} 24.71^{\prime \prime} \mathrm{N}$ & $91^{\circ} 45^{\prime} 21.53^{\prime \prime} \mathrm{E}$ \\
4 & Fatikchhari Canal & $22^{\circ} 43^{\prime} 16.12^{\prime \prime} \mathrm{N}$ & $91^{\circ} 45^{\prime} 41.39^{\prime \prime} \mathrm{E}$ \\
5 & Haruwalchhari Canal & $22^{\circ} 41^{\prime} 57.31^{\prime \prime} \mathrm{N}$ & $91^{\circ} 45^{\prime} 29.44 " \mathrm{E}$ \\
6 & Dhurang tributary stream & $22^{\circ} 40^{\prime} 40.89^{\prime \prime} \mathrm{N}$ & $91^{\circ} 46^{\prime} 32.71^{\prime \prime} \mathrm{E}$ \\
7 & Telpari Canal & $22^{\circ} 32^{\prime} 56.67^{\prime \prime} \mathrm{N}$ & $91^{\circ} 50^{\prime} 39.65^{\prime \prime} \mathrm{E}$ \\
8 & Sharta Canal & $22^{\circ} 31^{\prime} 6.88^{\prime \prime} \mathrm{N}$ & $91^{\circ} 50^{\prime} 55.24^{\prime \prime} \mathrm{E}$ \\
9 & Boalia Canal & $22^{\circ} 30^{\prime} 56.50^{\prime \prime} \mathrm{N}$ & $91^{\circ} 50^{\prime} 31.16^{\prime \prime} \mathrm{E}$ \\
10 & BWDB Irrigation project & $22^{\circ} 30^{\prime} 51.67^{\prime \prime} \mathrm{N}$ & $91^{\circ} 50^{\prime} 34.02^{\prime \prime} \mathrm{E}$ \\
11 & Khagatia Canal & $22^{\circ} 29^{\prime} 38.32^{\prime \prime} \mathrm{N}$ & $91^{\circ} 52^{\prime} 39.43^{\prime \prime} \mathrm{E}$ \\
12 & Mogdal Canal & $22^{\circ} 28^{\prime} 8.62^{\prime \prime} \mathrm{N}$ & $91^{\circ} 52^{\prime} 40.72^{\prime \prime} \mathrm{E}$ \\
13 & Kouis Canal & $22^{\circ} 25^{\prime} 50.12^{\prime \prime} \mathrm{N}$ & $91^{\circ} 52^{\prime} 36.81^{\prime \prime} \mathrm{E}$ \\
14 & Halda River downstream & $22^{\circ} 24^{\prime} 31.93^{\prime \prime} \mathrm{N}$ & $91^{\circ} 53^{\prime} 30.04^{\prime \prime} \mathrm{E}$ \\
\hline
\end{tabular}

\subsubsection{Calibration}

After importing all the necessary input parameters into the model, the model is simulated. Panchpukuria station flow data were used to calibrate and validate the flow outcome. From the trend analysis, the observed flow has been decreasing from 1985 to 2015. In 1999, the peak flow at the station was recorded around 550 cumecs. This model was calibrated for 2014 data at Panchpukuria station.

In order to calibrate the SWAT model, three parameters have been chosen - curve number, Available Water Capacity of the Soil Layer, Soil Evaporation Compensation Factor. Curve number helps to increase the peak discharge where the uncalibrated model peak discharge needs to be increased to match the observed discharge. Available water capacity of the soil layer is also the driving factor for the flow calibration. Available water capacity of the soil layer is inversely related to the rainfall-runoff. Soil evaporation compensation factor is increased; the overall flow of the model is increased. These parameters were selected through the trial-and-error process. Other parameters were not so effective to change the discharge of the overall model.

In order to ensure the calibration and validation of the model, correlation coefficient $R^{2}$ and Nash-Sutcliffe efficiency value have been used in the study. There are other parameters in the SWAT model, which are also accountable for model development. As long as the main focus on the model building is to estimate the river tributary discharge, the sensitivity analysis has not been performed; instead, the parameter values have been changed to calibrate the model (Fig. 4).
Model calibration parameters are stated in Table 3.

The correlation coefficient $\left(R^{2}\right)$ between model output and observed station flow equals 0.9732 which means the flow pattern in the existing scenario was matching with the model runoff scenario. Although the peaks of the model output and observed data do not coincide, the output shows better result during the low flow (April-May), which is more significant for the further sustainability analysis.

Model flow calibration at Panchpukuria station is shown in Fig. 5.

\subsubsection{Validation}

After model calibration was done, model output flow data were validated by 2012 discharge data of Panchpukuria station shown in Fig. 6.

The correlation coefficient gives a better understanding of the river discharge pattern, and the Nash-Sutcliffe efficiency helps to know the model performance. Concerning the scope of the study, the primary purpose of the model is to generate some discharge and water-level data which is needed to analyze the environmental condition. These model evaluation matrices are sufficient to validate the model. Additional statistical analysis of the working model can be done as future work of the study.

The correlation coefficient $\left(R^{2}\right)$ between model output and existing flow equals 0.9554 which is entirely satisfactory. The model output pattern matches with the observation data. The calculated value of Nash-Sutcliffe efficiency, NSE, is 0.924 which is closer to 1 [38]. It indicates that the model output and the existing discharge from the station are quite similar.

\subsubsection{Model output and analysis}

Output, the discharge graph of the observation points for the years 2000-2015, is demonstrated below (Fig. 7).

\subsection{Two-dimensional hydrodynamic modeling using Delft3D}

Although in recent times, the three-dimensional model is more famous for study and also would have provided more options for analysis. However, as per the research requirements the study was focused on a coupled analysis of hydrologic and hydrodynamic models focusing on the river flow and velocity impacts due to obstruction by dams. Already, the study is equipped with additional discharge outlets all along the river along with three dams, so a 3D model would have made it more complicated and time-consuming. Moreover, the research was also on a 
Fig. 3 Delineated watershed

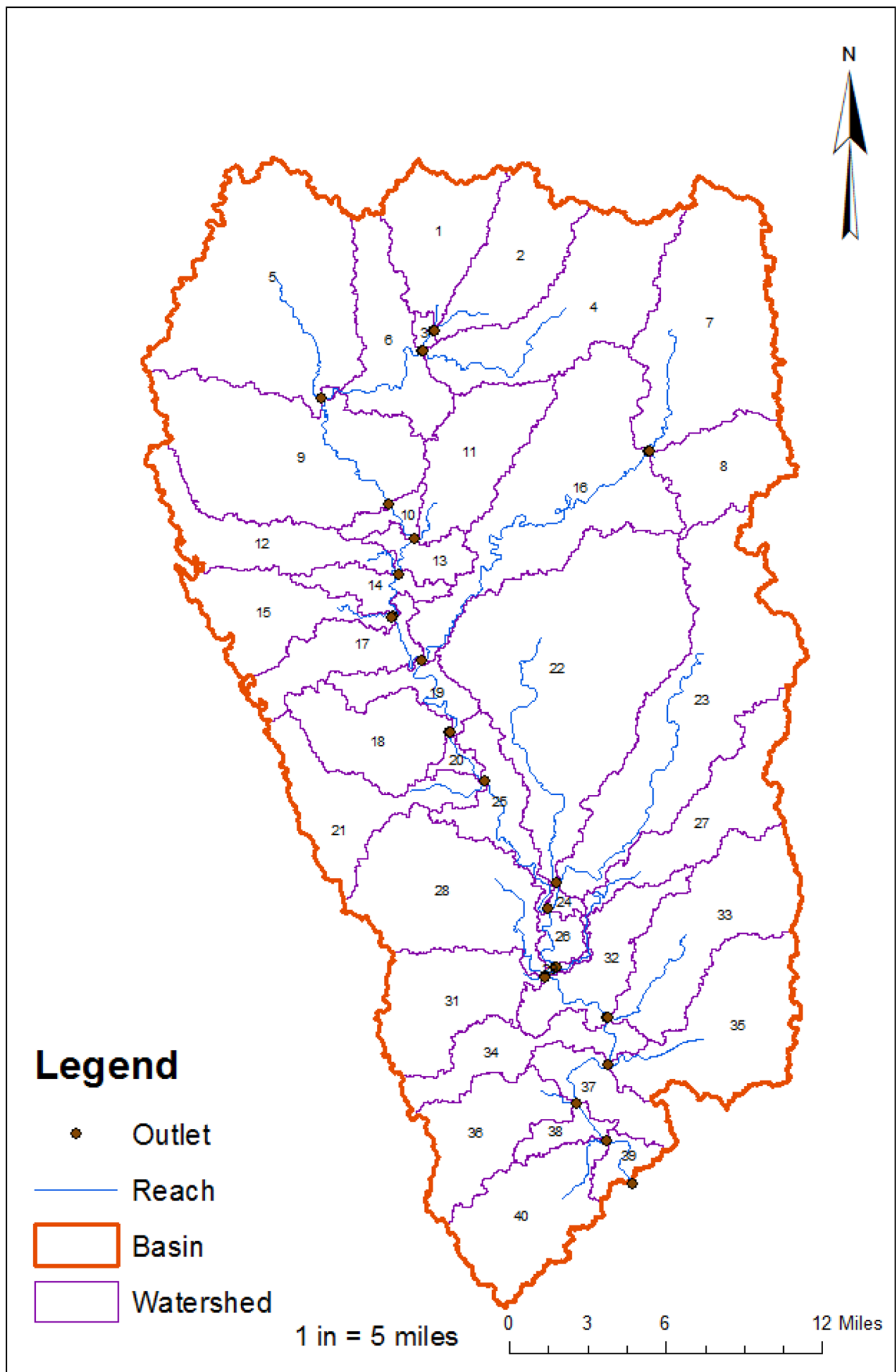

time constraint, that is why a two-dimensional model was developed for the flow regulation analysis.

Delft3D is a very stable and wide-open model to incorporate different parameters of a river in the hydrodynamic model from the hydrologic model [39]. Although there are a number of two-dimensional hydrodynamic models like HecRAS 2D, River 2D, they are not as flexible as the Delft3D.
In Delft3D, one of the most important features is to incorporate the inflows at different sections of the river generated from the hydrologic model, which is essential for our analysis. Moreover, the inclusion of Dam boundary at cross section and banks of the river is another important parameter for our flow regulation analysis, which is also another feature for Delft3D. Moreover, the selected model outputs 
Fig. 4 Daily rainfall-runoff from 2000 to 2015

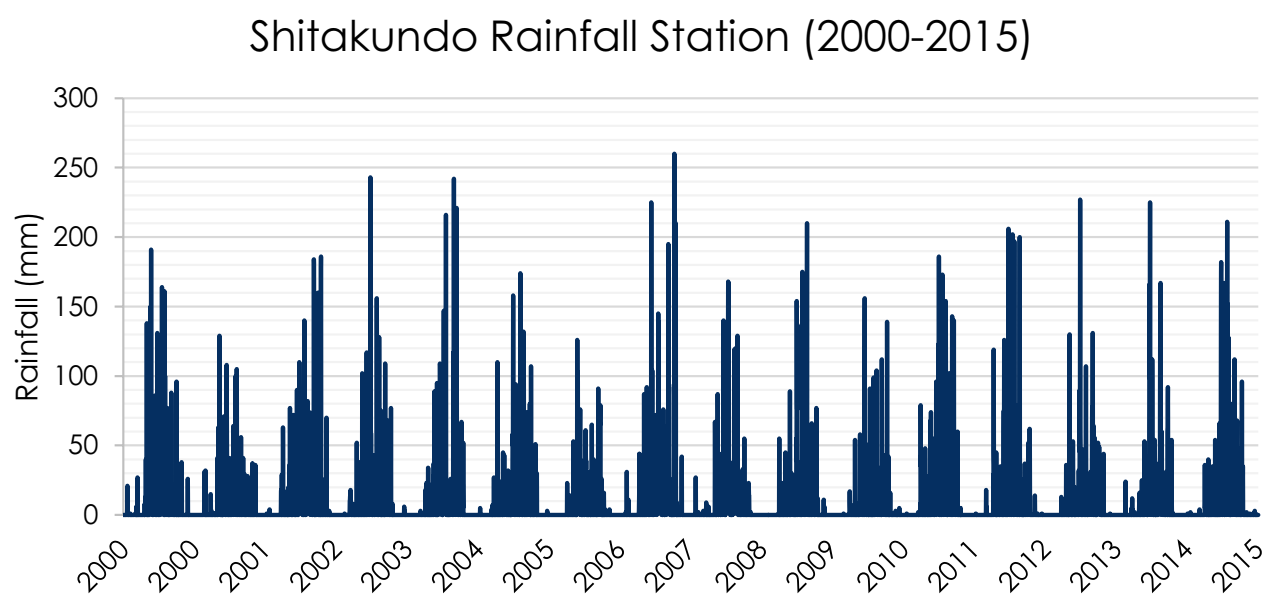

Table 3 Model calibration parameters

\begin{tabular}{|c|c|c|c|c|}
\hline Parameter & Description & $\begin{array}{l}\text { Before calibra- } \\
\text { tion }\end{array}$ & $\begin{array}{l}\text { Calibrated param- } \\
\text { eter }\end{array}$ & Comments \\
\hline $\mathrm{CN}$ & SCS curve number for moisture condition 2 & 80 & 85 & \multirow{2}{*}{$\begin{array}{l}\text { Helps to increase peak } \\
\text { discharge to match field } \\
\text { scenario }\end{array}$} \\
\hline $\begin{array}{l}\text { SOL_AWC (mm } \\
\left.\mathrm{H}_{2} \mathrm{O} / \mathrm{mm}\right)\end{array}$ & Available water capacity of the soil layer & 0.2 & 0.175 & \\
\hline ESCO & Soil evaporation compensation factor & 0.80 & 0.95 & Increase overall model flow \\
\hline
\end{tabular}

Fig. 5 Flow calibration at Panchpukuria station

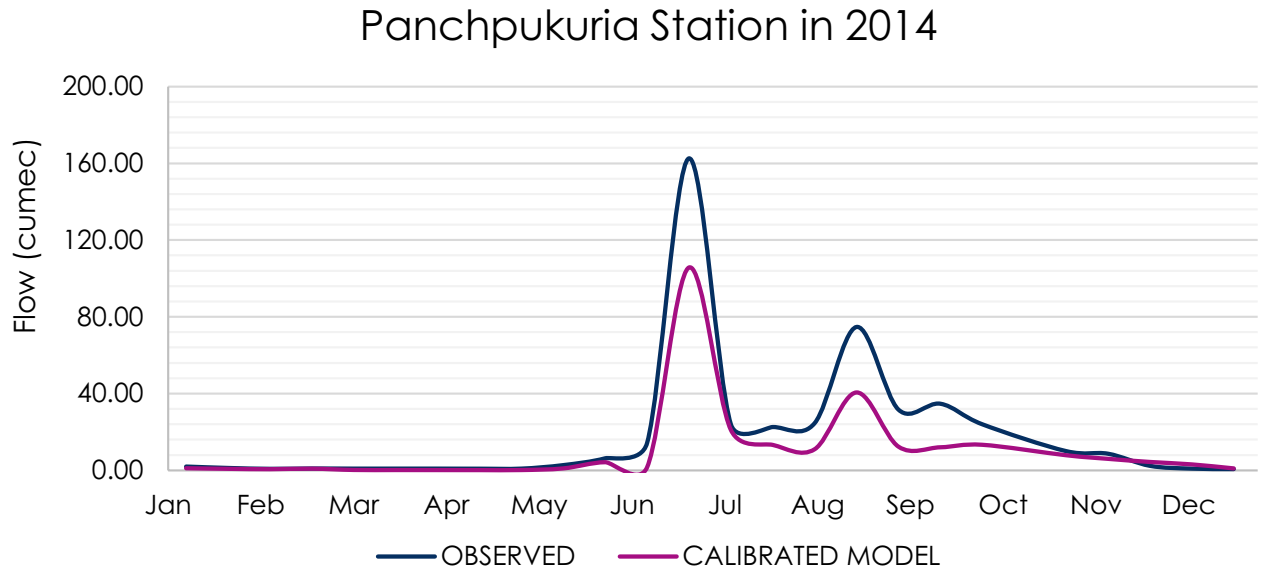

in Delft3D will not only generate the water level at each section but also will provide the necessary velocity for validation closer to the dams. All these analytical reasons led to the selection of Delft3D hydrodynamic model for the analysis of flow regulation impacts. The results obtained from hydrological simulations in ArcSWAT are incorporated into this model to study the flow regulation assessment.

\subsubsection{Data analysis}

The datasets include the morphological and boundary data collected from the Bangladesh Water Development Board (BWDB). Moreover, the discharge at each outlet from the hydrologic simulation is also utilized in this model (Table 4).

The upstream and downstream boundaries for the model are set up at Manikchhari Canal and Enayethat stations. The Manikchhari canal boundary discharge data for 2014 are generated from ArcSWAT model, and the Enayethat station water-level (WL) data are collected from the Bangladesh Water Development Board (BWDB) for 2014 (Fig. 8). 
Fig. 6 Flow validation at Panchpukuria station

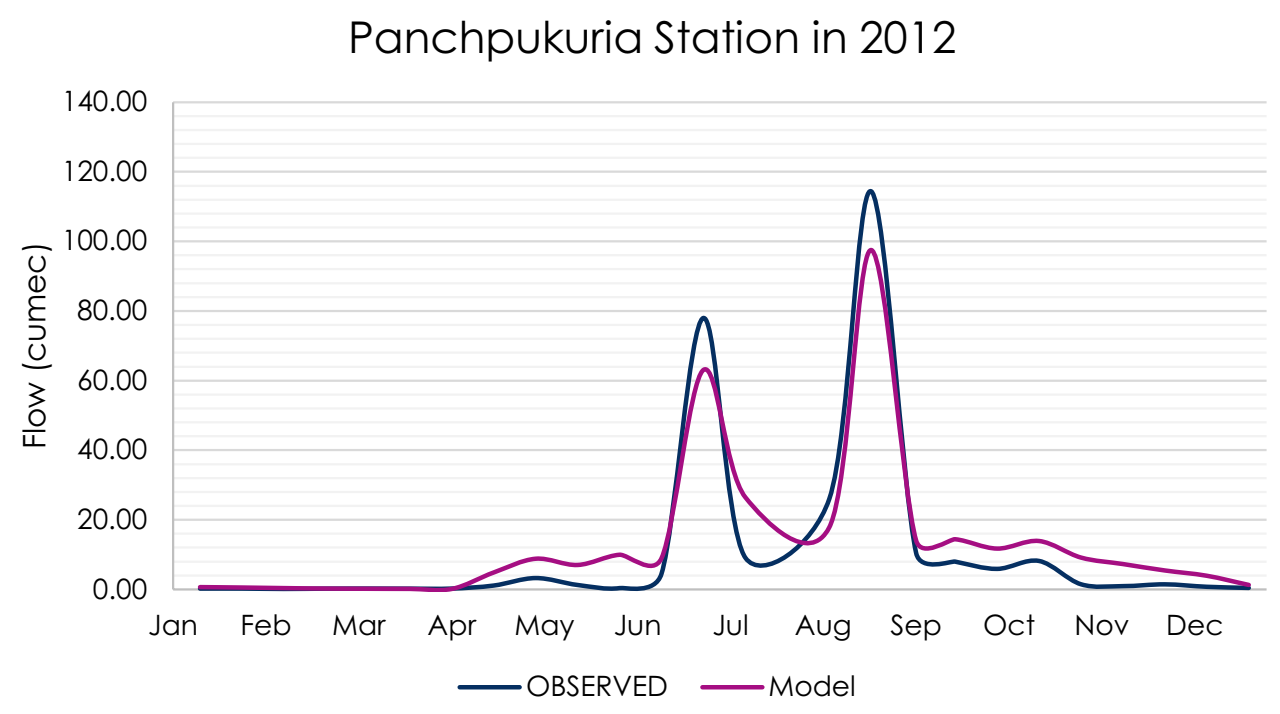

\subsubsection{Model development and simulation}

Bathymetry for the Halda model is formed for 2014 using 12 cross-sectional data collected from Bangladesh Water Development Board (BWDB) with coordinates and depths. Coordinates for the station are used to generate the individual coordinates for depth in Bangladesh Transverse Mercator (BTM) using ArcGIS. The generated coordinates as $x, y$ and depths are $z$ arranged in a text file and saved as sample file (*.xyz). Land boundary is exported from Quickplot using shapefile of the Halda River. Then, the land boundary file is imported in RGF-GRID to generate splines. Finally, with appropriate orthogonal values $(m, n)$, the splines are converted to grid. The generated grid and sample files are then imported to QUICKIN.

There are two methods of data interpolation in Delft3D for bathymetry. One is Grid Cell Average and another one is Triangular Interpolation. Grid Cell Average is preferred when the spatial availability of data is higher than the grid size as data need to be averaged at the center of cells, whereas Triangular Interpolation is preferred when the data resolution is less than the grid size as data need to be generated by triangular interpolation network. In our study, the grid size is much smaller than the resolution of topography data, so Triangular Interpolation is adopted to interpolate the grid. Using Triangular Interpolation, the grid is interpolated with a sample file. With smoothing and diffusion, the course file is smoothened and finally exported as depth file for the model.

After the bathymetry setup, grid and depth files are imported in domain and simulation is set for the year 2014 with time step of $1 \mathrm{~min}$. Moreover, the initial condition of the water level is set for Manikchhari station in the model. Upstream and downstream boundaries at Manikchhari and Enayethat are identified on the bathymetry and selected for input. The discharge data for Manikchhari and water-level data for Enayethat are incorporated in the time-series file of the boundary. The critical parameter in this model is the Manning's coefficient. Initially, the model is simulated in some possible values ranging from 0.015 to 0.045 for dam scenarios to calibrate the model.

The outlet discharges of Halda River are initially generated from the hydrologic model and which is finally incorporated in Delft3D as point discharges. To calibrate the model, we selected observation points at Narayanhat and Telpari water-level stations. Moreover, to generate the dam and without dam scenarios, we identified three locations just below the major dams of the Halda River as Bhujpur rubber dam, Haruwalchhari Dam and BWDB Irrigation Canal Dam. The model is finally simulated for the year 2014 with an expected output of 3-h interval. The model is also simulated for April 2014 and November 2014 to calibrate and validate the model.

\subsubsection{Calibration}

The model is calibrated for April 2014 for four values of Manning's coefficient, and the results of the correlation coefficient are shown below. The water-level data generated for four different scenarios of Manning's coefficient are plotted with the observed water level and shown in the graph. The graphs are plotted for water-level stations Telpari and Narayanhat (Table 5; Figs. 9 and 10).

Although the best values for calibration are, respectively, $n=0.045$ and $n=0.035$, considering both, 0.035 shows the best value for the model. So, finally, $n=0.035$ is selected for model simulation. 


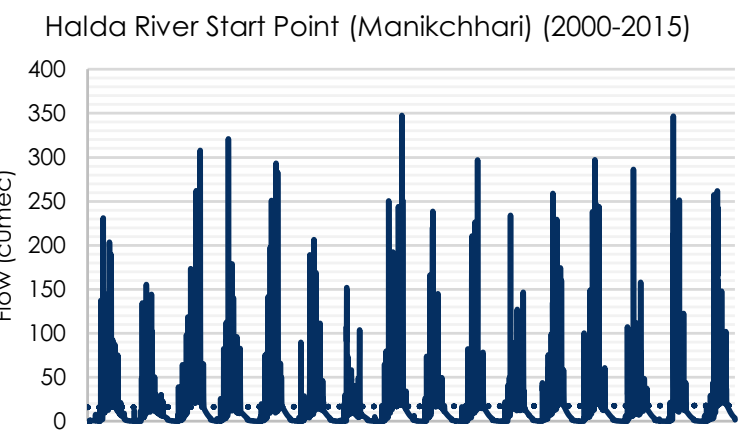

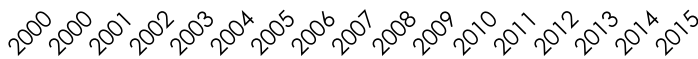

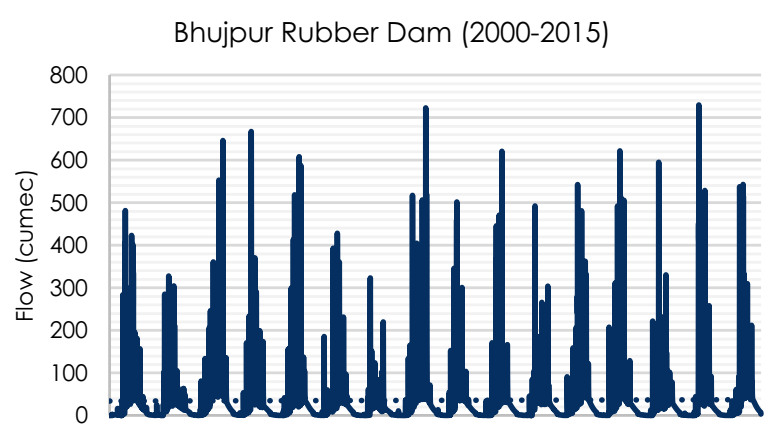

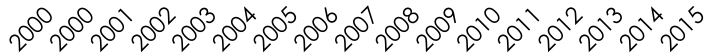

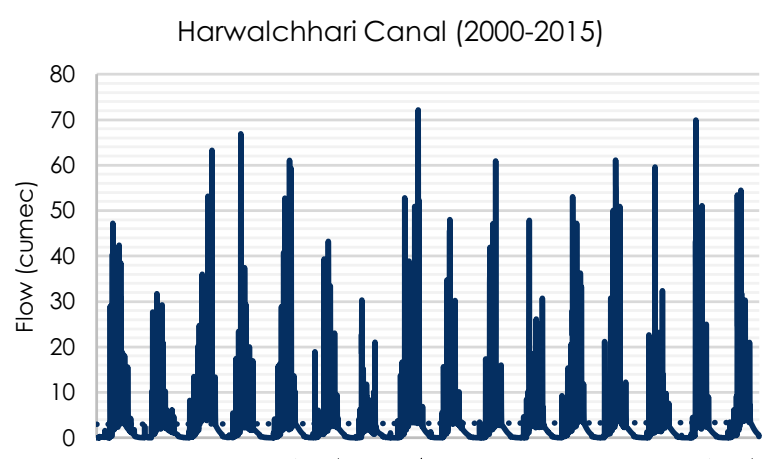

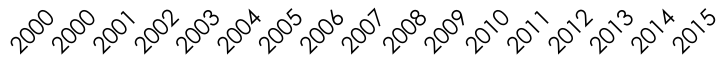

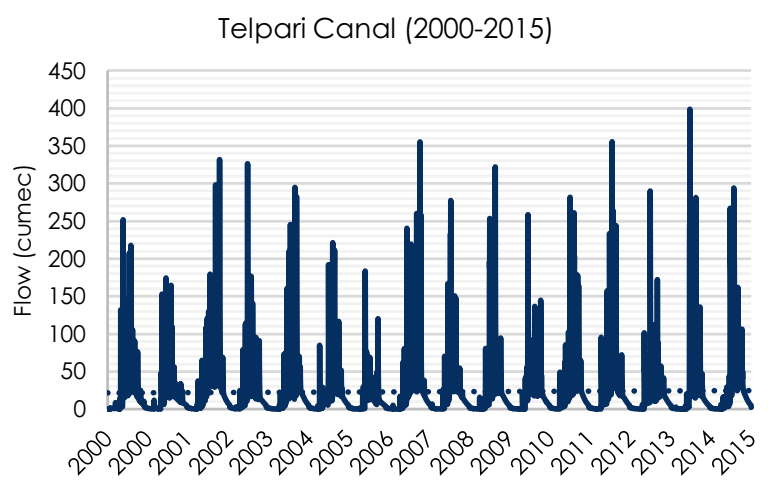

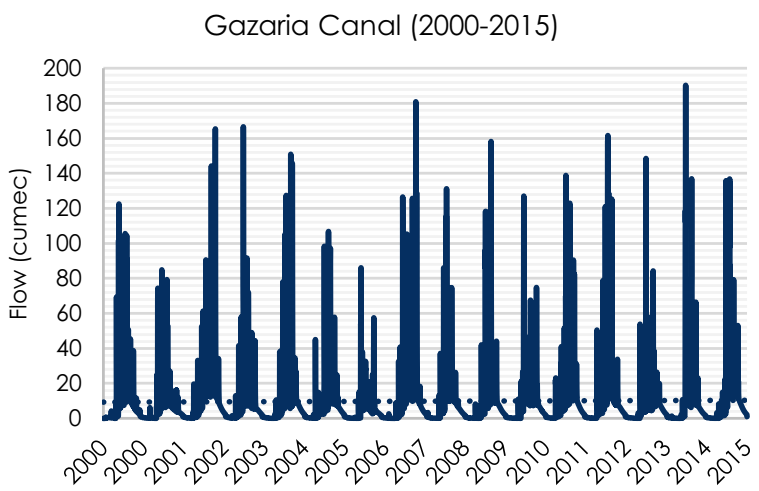
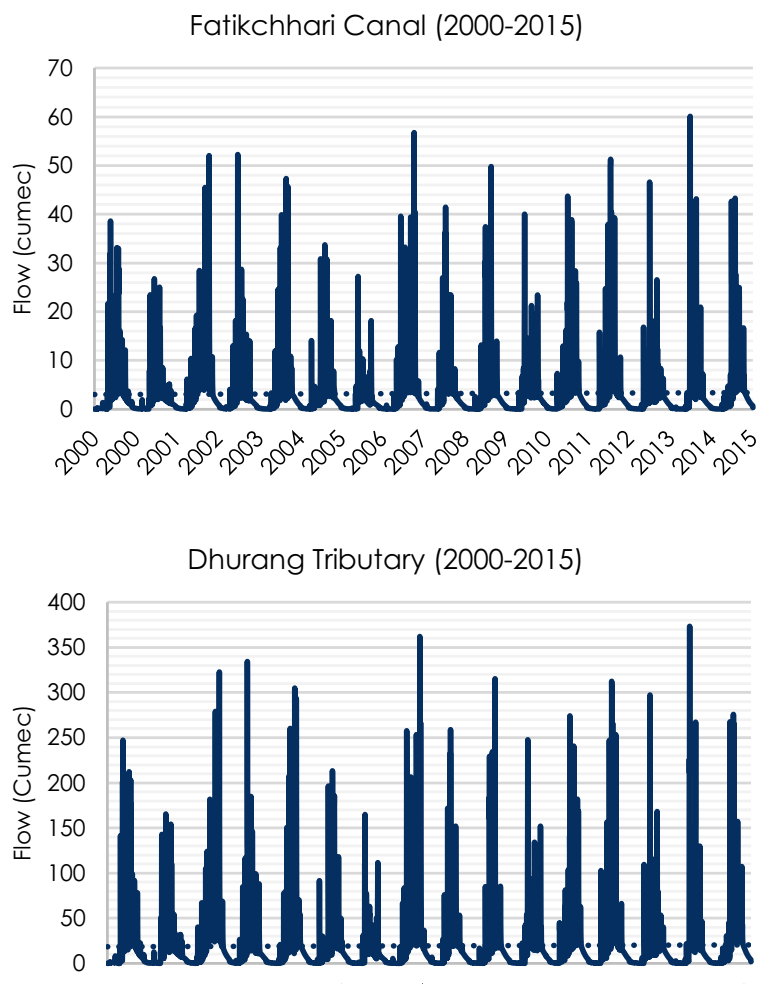

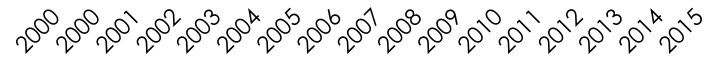

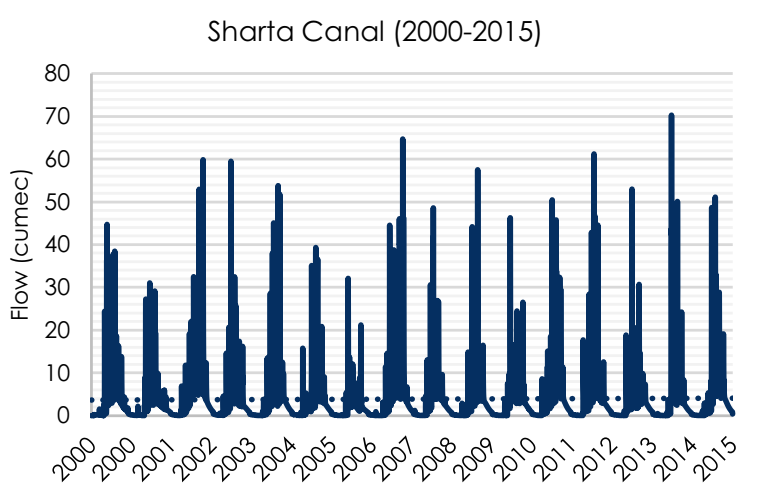

Fig. 7 Discharge graph of the observation points for the years 2000-2015 


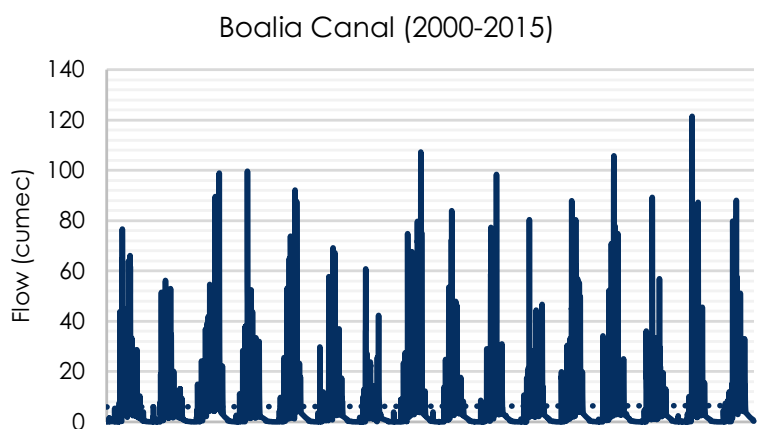

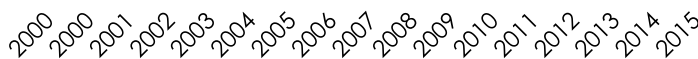

Khagatia Canal (2000-2015)

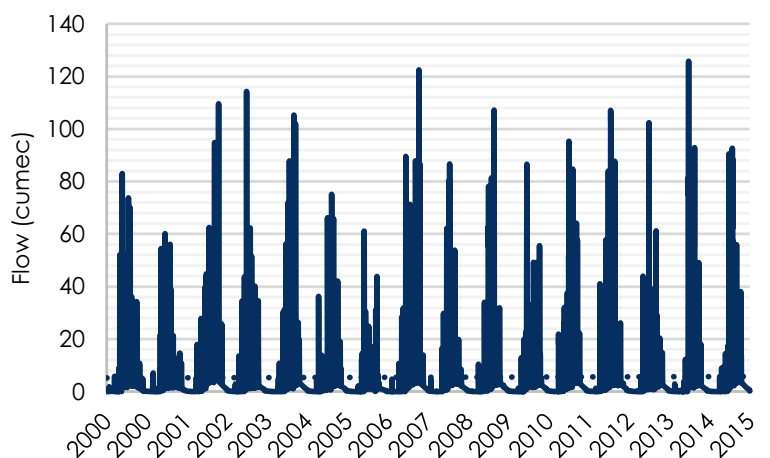

Kouis Canal (2000-2015)

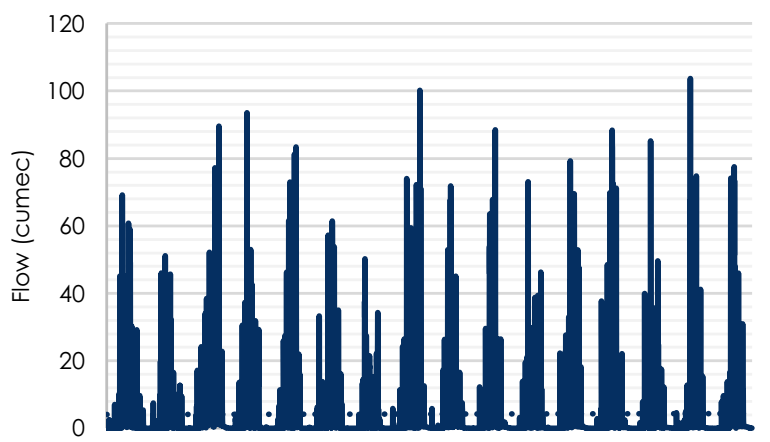

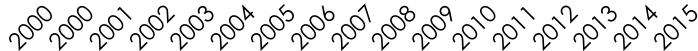

BWDB Irrigation Canal (2000-2015)

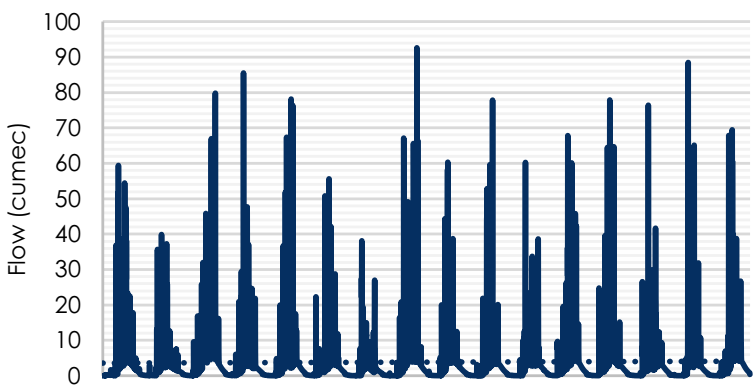

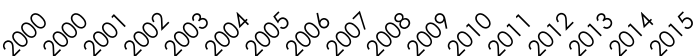

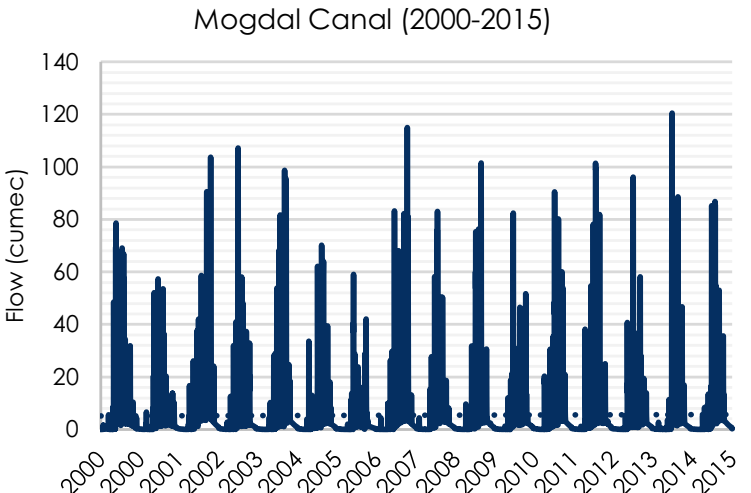

Halda River Downstream (2000-2015)

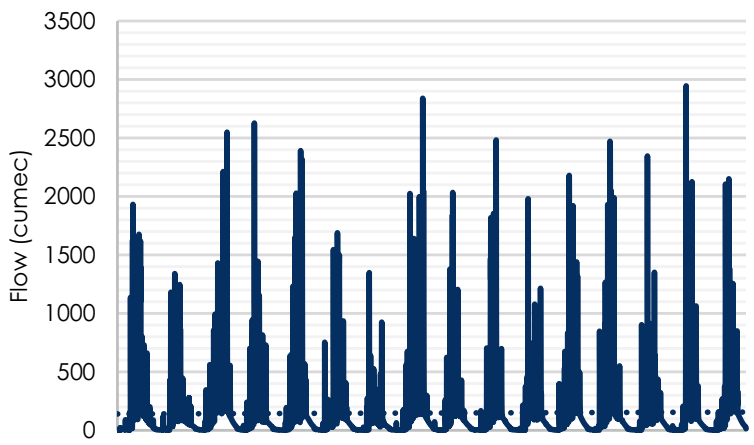

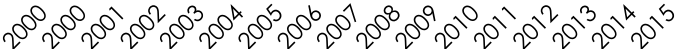

Fig. 7 (continued)

Table 4 Description of the datasets used for the hydrodynamic model

\begin{tabular}{llll}
\hline Data & Source & Extent & Resolution \\
\hline River morphological data & $\begin{array}{c}\text { Bangladesh Water } \\
\text { Development } \\
\text { Board (2012) }\end{array}$ & Halda River & Along the reach \\
Discharge data & Hydrologic Model & Canals connected to river stream & Data per day \\
Water-level data & Bangladesh Water & Halda River downstream & Data per day \\
& Development & & \\
& Board (2012) & & \\
\hline
\end{tabular}


Fig. 8 Boundary conditions at Manikchhari Canal and Enayethat stations
Manikchhari Station- 2014

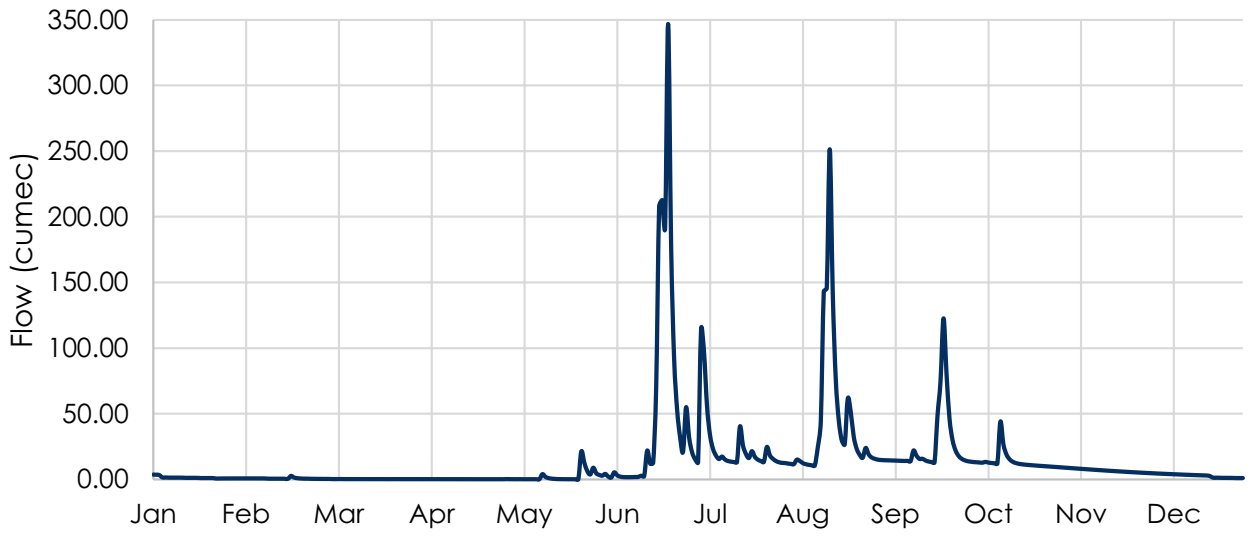

Enayethat Station- 2014

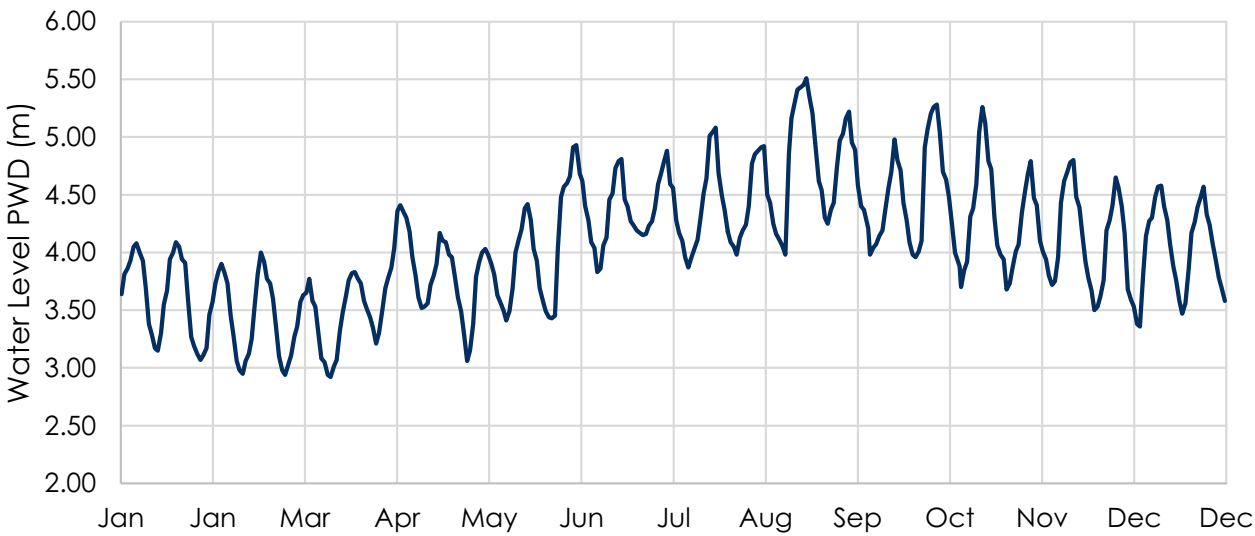

Table 5 Correlation of Manning's coefficients

\begin{tabular}{llllll}
\hline Analysis & $\begin{array}{l}\text { Station } \\
\text { name }\end{array}$ & \multicolumn{4}{l}{ Correlation coefficients for calibration, $R^{2}$} \\
\cline { 3 - 6 } & $N=0.015$ & $n=0.025$ & $n=0.035$ & $n=0.045$ \\
\hline Calibration & Telpari & 0.78 & 0.82 & 0.85 & 0.86 \\
& $\begin{array}{l}\text { Narayan- } \\
\text { hat }\end{array}$ & 0.92 & 0.92 & 0.92 & 0.92 \\
\multirow{5}{*}{ Validation } & & & & \\
& Telpari & 0.92 & 0.88 & 0.85 & 0.81 \\
& $\begin{array}{c}\text { Narayan- } \\
\text { hat }\end{array}$ & 0.82 & 0.82 & 0.82 & 0.82 \\
& hat & & & & \\
\hline
\end{tabular}

\subsubsection{Validation}

The model is further validated for April 2014 for selected Manning's coefficient of 0.035 in the Panchpukuria station. The velocity data generated for Manning's coefficient of $n=0.035$ are plotted with the observed water level and shown in the graph (Fig. 11).

\section{Results}

\subsection{Dam scenarios}

In Halda River, the dams are usually open during the monsoon season and closed during the summer season due to the scarcity of flow. Moreover, as during the dry period, the irrigation water is the primary concern, the dams remain closed during that time to conserve water at the upstream. Therefore, to assess the change of flow and velocity in the river due to the closing and opening of the dams, these two types of scenarios are adopted for the analysis. So, these two types of scenarios will be generated in this section. Velocity profile will be generated from the model for Bhujpur Rubber Dam, Haruwalchhari Rubber Dam, and BWDB Irrigation Canal Dam showing dam and without dam conditions. This scenario will help us to understand the suitability of fish habitats to lay eggs in these specified regions of the river. 
Fig. 9 Calibration at Telpari BWDB station

Fig. 10 Calibration at Narayanhat BWDB station

Fig. 11 Velocity validation at Panchpukuria BWDB station
Telpari Station Calibration- 2014

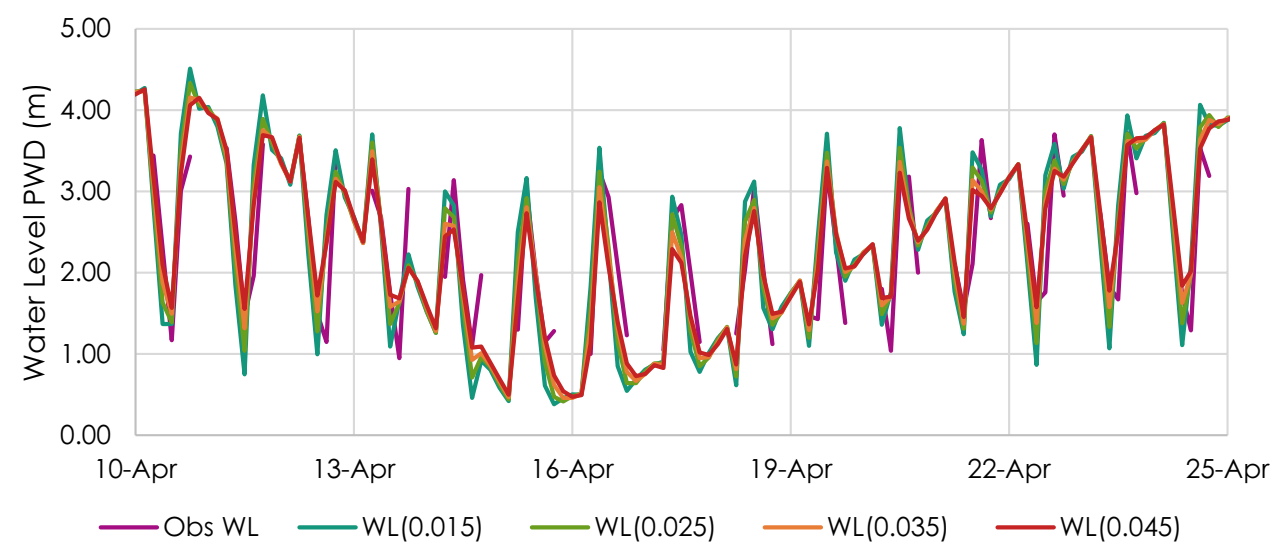

Narayanhat Station Calibration- 2014

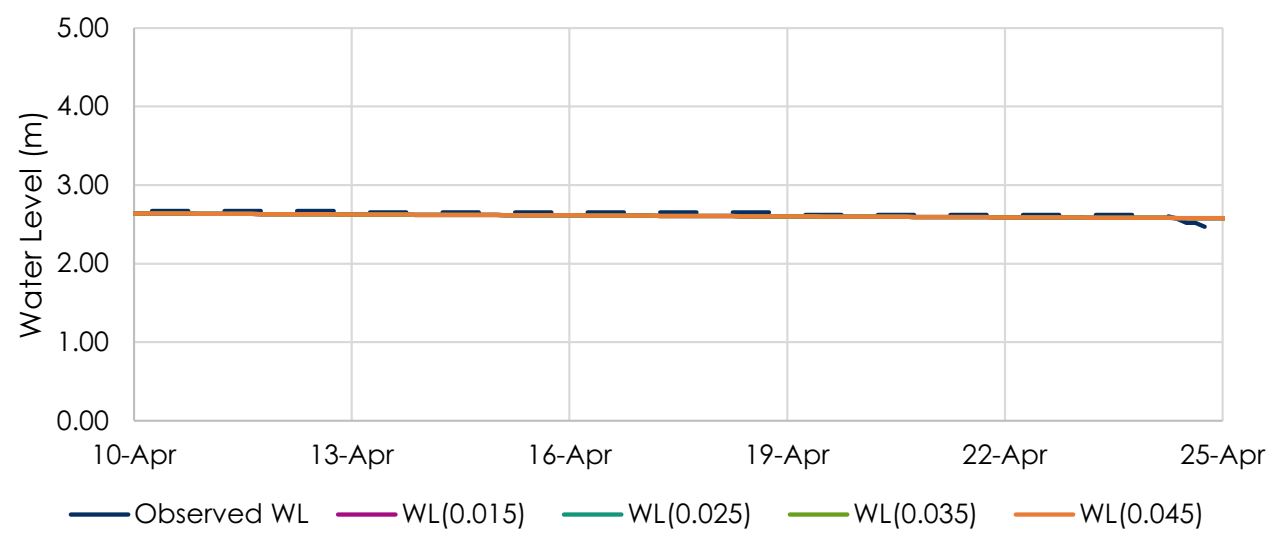

Panchpukuria Station Validation- 2014

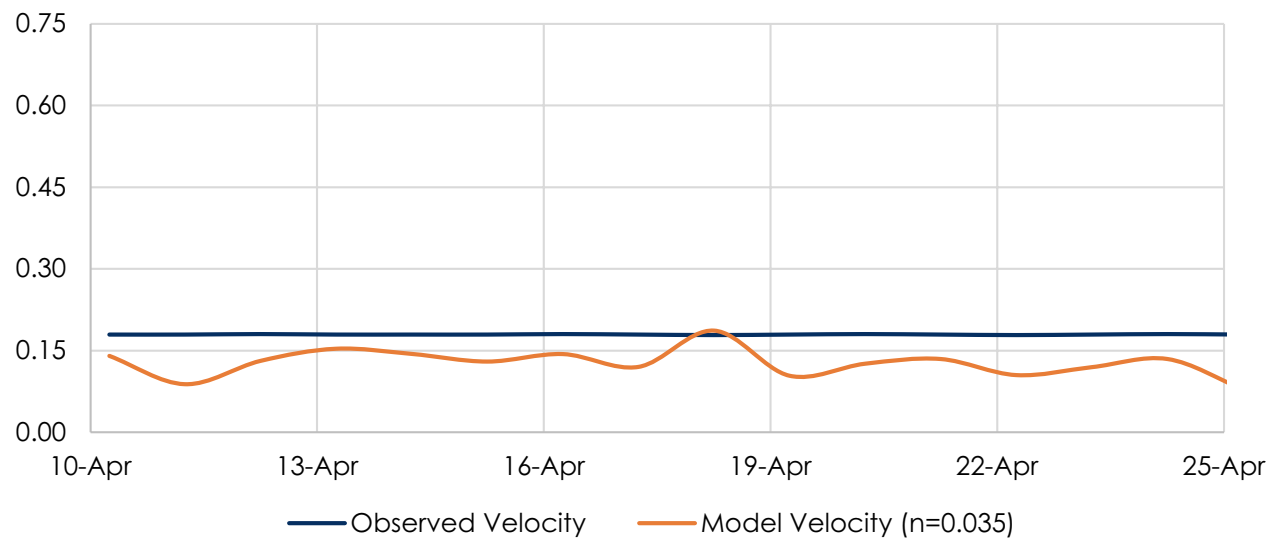

\subsubsection{Velocity profiles for Bhujpur Rubber Dam}

Bhujpur Rubber Dam is located on the Halda River in Bhujpur Thana of Chittagong District. A graph has been developed with depth average velocity data extracted from Delft3D model for 2014 (Fig. 12).

Observation from the graph of velocity profile is as follows: 
Fig. 12 Velocity profiles for Bhujpur rubber dam
Bhujpur Rubber Dam Velocity Profile- 2014

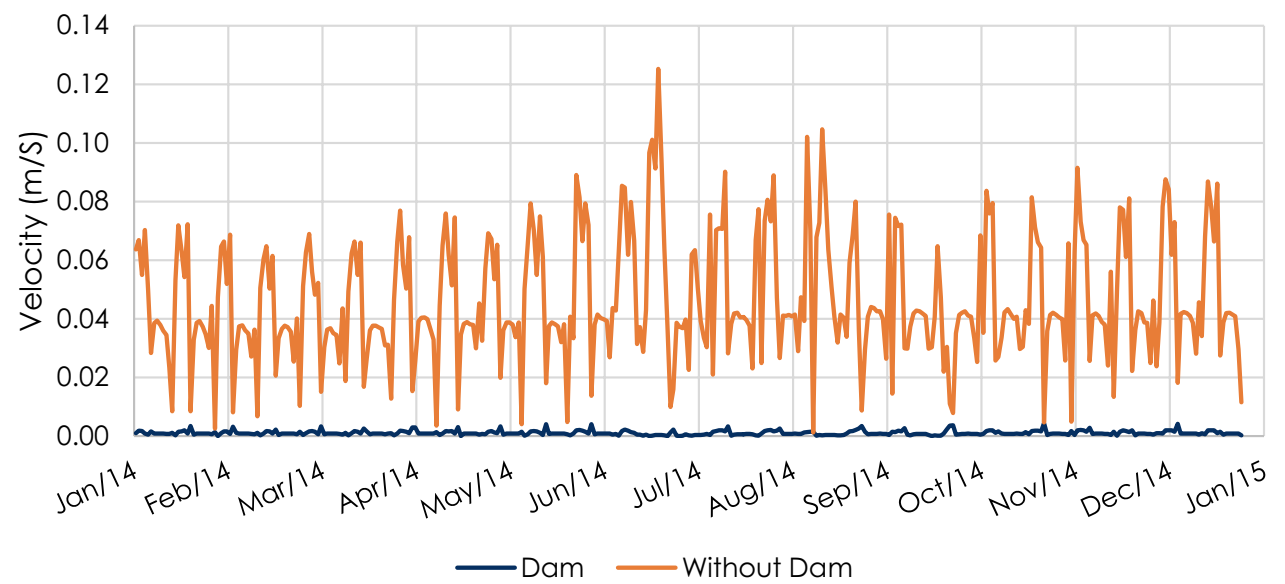

- Velocity increases from January to July and is as high as $0.13 \mathrm{~m} / \mathrm{s}$ and decreases from August to December and is as low as $0.0012 \mathrm{~m} / \mathrm{s}$ without the dam.

- Velocity increases from January to July and is as high as $0.0044 \mathrm{~m} / \mathrm{s}$ and decreases from August to December and is as low as $0.00 \mathrm{~m} / \mathrm{s}$ without the dam.

- The average velocity with the dam is $0.0010 \mathrm{~m} / \mathrm{s}$ and without dam is $0.0461 \mathrm{~m} / \mathrm{s}$.

- Velocity is high during monsoon (June-October) and low during winter (November to April) for without dam condition.

- Velocity is flat and almost the same for dam condition all over the years which is suitable for fishes to lay eggs in this region of the river.

\subsubsection{Velocity profiles for Haruwalchhari Canal Dam}

Haruwalchhari Rubber Dam is located on the Haruwalchhari Canal of Halda River in Haruwalchhari Thana of
Chittagong District. A graph has been developed with depth average velocity data extracted from Delft3D model for 2014 (Fig. 13).

Observation from the graph of velocity profile is as follows.

- Velocity increases from January to July and is as high as $0.56 \mathrm{~m} / \mathrm{s}$ and decreases from August to December and is as low as $0.0037 \mathrm{~m} / \mathrm{s}$ without the dam.

- Velocity increases from January to July and is as high as $0.26 \mathrm{~m} / \mathrm{s}$ and decreases from August to December and is as low as $0.0037 \mathrm{~m} / \mathrm{s}$ without the dam.

- The average velocity with the dam is $0.09 \mathrm{~m} / \mathrm{s}$ and without the dam is $0.20 \mathrm{~m} / \mathrm{s}$.

- Velocity is high during monsoon (June-October) and low during winter (November to April) for without dam condition.
Fig. 13 Velocity profiles for Haruwalchhari Canal dam
Haruwalchhari Canal Velocity Profile- 2014

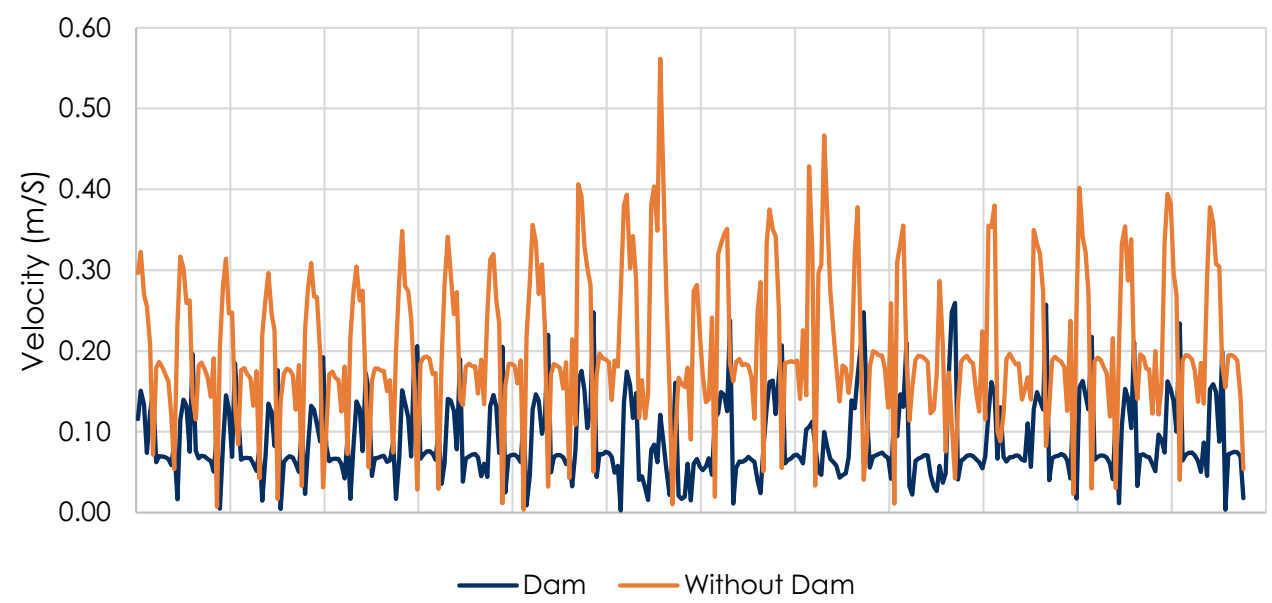


- Velocity is less fluctuating and almost the same for dam condition all over the years which is suitable for fishes to lay eggs in this region of the river.

\subsubsection{Velocity profiles for BWDB Irrigation Canal Dam}

BWDB Irrigation Canal Rubber Dam is located on the BWDB Irrigation Canal of Halda River in Hathazari Thana of Chittagong District. A graph has been developed with depth average velocity data extracted from Delft3D model for 2014 (Fig. 14).

Observation from the graph of velocity profile is as follows:

- Velocity increases from January to July and is as high as $3.04 \mathrm{~m} / \mathrm{s}$ and decreases from August to December and is as low as $0.0068 \mathrm{~m} / \mathrm{s}$ without the dam.

- Velocity increases from January to July and is as high as $2.60 \mathrm{~m} / \mathrm{s}$ and decreases from August to December and is as low as $0.01 \mathrm{~m} / \mathrm{s}$ without the dam.

- The average velocity with the dam is $0.51 \mathrm{~m} / \mathrm{s}$ and without the dam is $0.52 \mathrm{~m} / \mathrm{s}$.

- Velocity is high during monsoon (June-October) and low during winter (November to April) for without dam condition.

- Velocity is very fluctuating and changes during monsoon and winter for dam condition which is unsuitable for fishes to lay eggs in this region of the river.

\subsection{Environmental flow analysis}

There are four types of approaches for performing the environmental flow analysis of a river. They are hydrologic index model, hydraulic models, habitat models and holistic model. Tennant method is a hydrologic index model where specific discharge margin values are used to analyze the fish breeding condition of river Halda. According to Tennant's findings, a flow of $30 \%$ of the average annual flow is required to maintain a suitable habitat for aquatic life and that an optimal habitat is provided by flows of $60-100 \%$ of the average annual flow and flushing flows are $200 \%$ of the average annual flow [19]. Lyons method is an alternative method to the Tennant method, which is derived from Tennant method. According to Lyons method during October-February, $40 \%$ of the median flows by month and during March-September $60 \%$ of the median flows by month are the environmental flow targets. The $60 \%$ level is chosen to be more protective of the riverine ecosystem during the spring and summer periods, which are considered most critical to the warm water fisheries found in Texas [40]. The other four methods for hydrologic index modeling technique are biological flows, indicator of hydrologic alteration [41], the range of variability approach (RVA) [24] and the hydrologic assessment tool which was proposed by [25]. All these approaches for the environmental flow analysis are both tangible and intangible. So, none of them can be compared excellent or bad with the other approaches. The best way to do the environmental flow assessment is to follow the past research record or, doing some comparison study to perform the flow assessment [22]. Therefore, it was realized that Tennant method would be the most suitable method for the flow analysis [42].

Tennant method is used to perform building block analysis for fish habitat and spawning in the river area. April-May is the primary breeding time for carp fishes in the river. Here, the monthly average flow is compared to

\section{BWDB Irrigation Canal Velocity Profile- 2014}

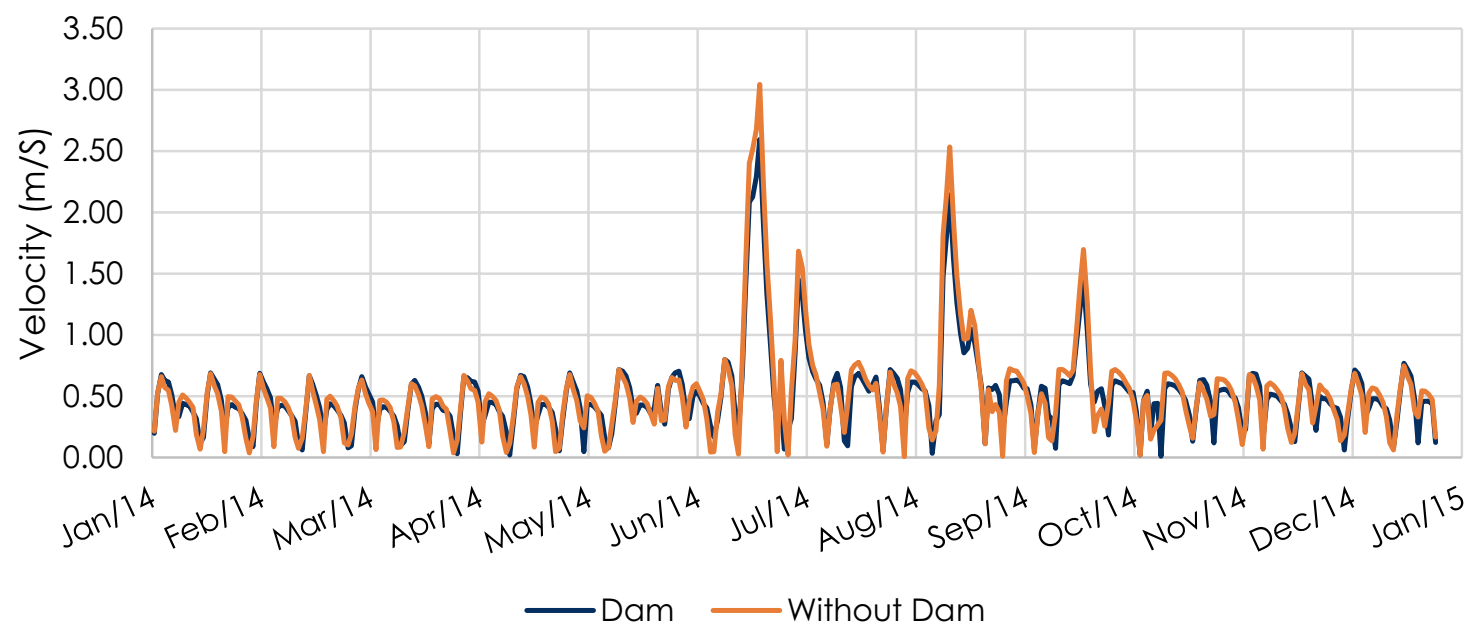

Fig. 14 Velocity profiles for BWDB Irrigation Canal dam 
the required river flow for safe fish habitat and breeding process. Tennant assumptions [43] about fish habitat and ecological condition in river flow have been utilized in the building block method. Bhujpur Rubber Dam, Haruwalchhari Dam and BWDB irrigation canal outlets are analyzed in the process. Three graphical comparison and observations in those three locations are demonstrated according to Tennant method (Table 6).

\subsubsection{Bhujpur Dam}

See Fig. 15.

Table 6 Calculation using

Tennant method

Fig. 15 Building block analysis of Bhujpur dam
Observations from graph.

- From the Tennant method, monthly average flow is observed less than the good and fair requirement in April.

- Due to less flow in month April, fish habitat is at stake in that location.

- From the graph, the peak monthly flow is around eight cumecs, and it is observed in July.

\subsubsection{Haruwalchhari Dam}

See Fig. 16.

\begin{tabular}{llll}
\hline Location & Bhujpur dam & Haruwalchhari dam & BWDB Irrigation Canal \\
\hline $\begin{array}{l}\text { Period of record } \\
\text { Mean annual flow }\left(\mathrm{m}^{3} \mathrm{~s}\right)\end{array}$ & $2000-2015$ & $2000-2015$ & $2000-2015$ \\
$\begin{array}{l}\text { Flushing or max } \\
\text { Apr to Sept @ 200\% }\end{array}$ & 6.16 & 50.29 & 129.2 \\
Outstanding & & 100.57 & 258.38 \\
Apr to Sept @ 60\% & 1.89 & & \\
Oct to Mar @ 40\% & 1.26 & 30.2 & 77.5 \\
Excellent & & 20.11 & 51.68 \\
Apr to Sept@ 50\% & 1.58 & & 64.6 \\
Oct to Mar @ 30\% & 0.95 & 25.1 & 38.76 \\
Good & & 15.09 & 51.7 \\
Apr to Sept @ 40\% & 1.26 & & 25.84 \\
Oct to Mar @ 20\% & 0.63 & 20.1 & 38.8 \\
Fair or grading & & 10.06 & 12.92 \\
Apr to Sept@ 30\% & 0.95 & & 12.9 \\
Oct to Mar @ 10\% & 0.32 & 15.1 & $<12.92$ \\
Poor or min & & 5.03 & \\
Oct to Sept @ 10\% & 0.32 & 15.1 & \\
Serve degradation & & $<15.09$ & \\
Apr to Sept @ < 10\% & $<0.32$ & & \\
\hline
\end{tabular}

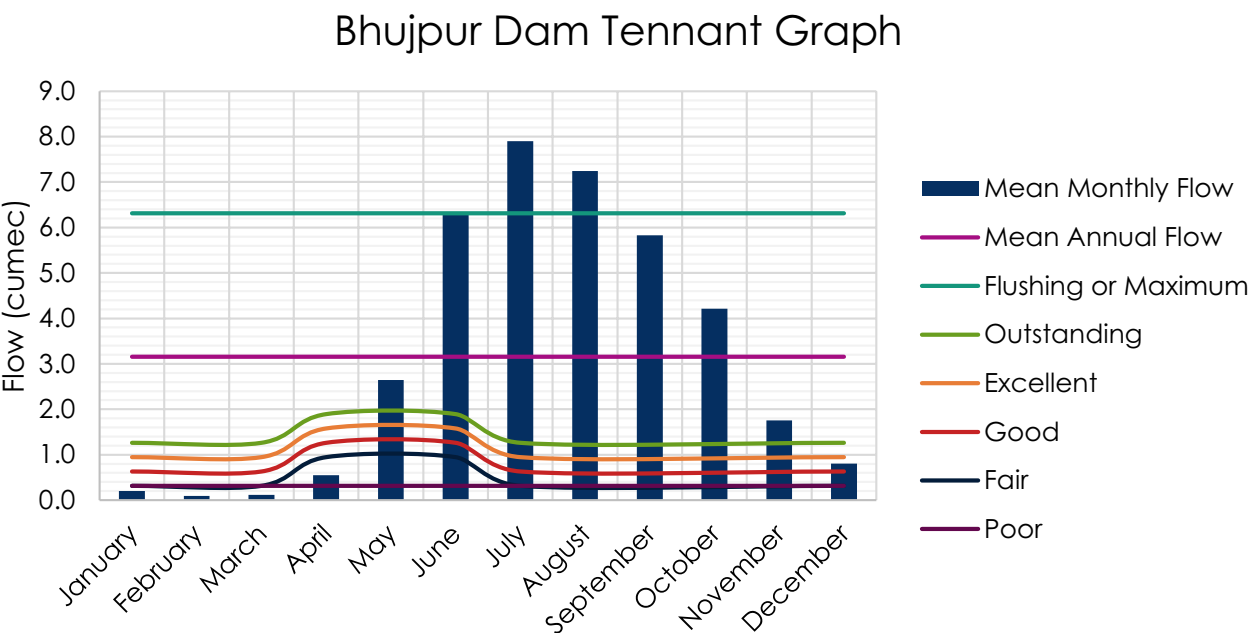


Fig. 16 Building block analysis of Haruwalchhari dam

\section{Haruwalchhari Dam Tennant Graph}

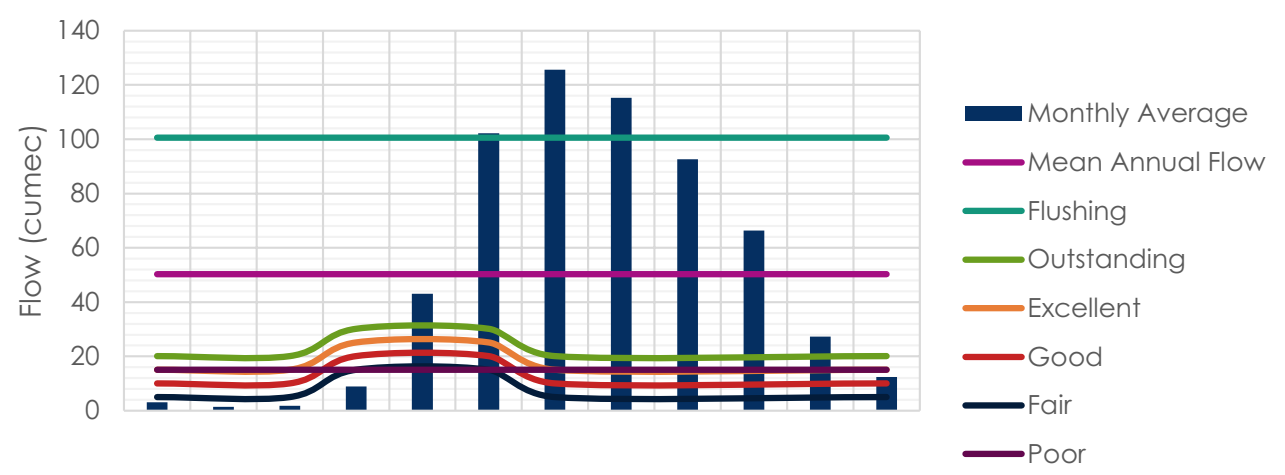

Observations from graph:

- From the Tennant method, monthly average flow is observed less than the good and fair requirement in April.

- Due to less flow in month April, fish habitat is at stake in that location.

- From the graph, the peak monthly flow is around 126 cumecs, and it is observed in July.

\subsubsection{BWDB Irrigation Canal Dam}

See Fig. 17.

Observations from graph:

- From the Tennant method, monthly average flow is observed less than the good and fair requirement in April.

- Due to less flow in month April, fish habitat is at stake in that location.

- From the graph, the peak monthly flow is around 325 cumecs, and it is observed in July.

\section{Conclusions}

The hydrologic model is developed in ArcSWAT for 2000-2015 incorporating digital elevation model, digitized stream and other land-use parameters. The model is simulated for output of discharge at 14 locations. The result shows average discharge for the selected areas is almost similar for the last 15 years and in many cases are in increasing trend. Later, the hydrodynamic model is developed in Delft3D for 2014 incorporating the data collected from Bangladesh Water Development Board and also the data generated for outlets in the hydrologic model. The model is then simulated for the dam and without dam scenarios. The velocity profile shows the water is almost static in Bhujpur Dam and has low flows at Haruwalchhari and BWDB irrigation canal dams. Such restriction of flows is not recommendable for fish breeding and spawning processes. Minimum flow requirement for well fish habitat and spawning is analyzed by building block method using Tennant assumption. Here, the mean annual flow of Halda River is compared with the monthly average flow. As April-May is vital for Halda River fish breeding process, enough water flow is required. From the above analysis,
Fig. 17 Building block analysis of BWDB Irrigation Canal

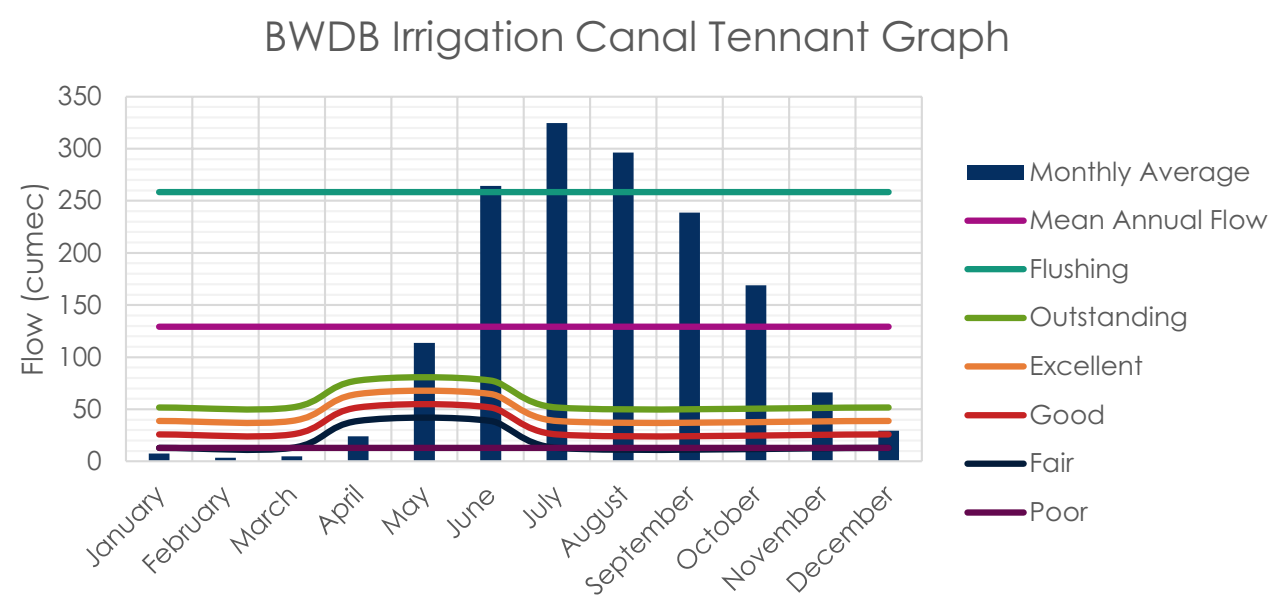


month April has been found vulnerable for good fish habitat and breeding process. From the above analysis, it can be concluded that the rubber dams constructed on the river course are severely demolishing the ecological condition of safe fish habitat and breeding process in river Halda. So, sustainable approaches must be implemented by the public-private collaboration to maintain the integrity of the only natural carp breeding river of the country.

The significant drawback and limitation for the environmental flow analysis of Halda river were the unavailability of the recent data on topography, rainfall, river flow and water level. In this research, a coupled simulation of the hydrologic model ArcSWAT and Delft3D has been built to assess the contribution of rainfall on the river flow output from the tributaries. The research findings help us to distinguish the effect of the dams on the fish breeding condition for the change in velocity of the river flow. Finally, Tennant method has been followed in the study to perform the environment flow analysis of the river. In the future, more research on the Halda River should focus on the recent data analysis along with studies based on the hydrology, ecology and biodiversity to formulate a risk management strategy.

Acknowledgements The research leading to these results has received funding from the United Nations Development Programme, Bangladesh UNDP-BD/CPS/2017 under Grant Agreement No. 011 (Conduct three feasibility studies on Halda River).

\section{Compliance with ethical standards}

Conflict of interest The authors declare that they have no conflict of interest.

\section{References}

1. The Daily Star (2014) Rubber dams render blow to ecosystem, 29 May 2014.

2. WRE (2016) Impact assessment on upstream water withdrawal to conserve natural breeding habitat of major carps in the River Halda. Department of Water Resources Engineering, Dhaka

3. Khan S, Azadi MA (2006) Studies and management strategies to revive and sustain the fisheries in the River Halda. A research project of MoFL and WorldFish Centre

4. Ronald PW, Azadi MA (1985) Hydrological conditions influencing the spawning of major carps in the Halda River, Chittagong, Bangladesh. Bangladesh J Zool 13(1):63-72

5. Azadi MA, Alam MA (2013) Ichthyofauna of the River Halda, Chittagong, Bangladesh. Bangladesh J Zool 41(2):113-133

6. The New Nation (2009) High salinity in Karnaphuli water hinders

7. Zaman F (2014) River Halda awakening: a research training and awareness. Department of Architecture, BRAC University, Dhaka

8. Islam MS, Akbar A, Akhtar A, Kibria MM, Bhuyan MS (2017) Water quality assessment along with pollution sources of the Halda River. J Asiatic Soc Bangladesh Sci 43:61-70

9. Kabir MH, Kibria MM, Jashimuddin M, Hossain MM (2013) Economic valuation of tangible resources from Halda-the carp spawning unique river located at Southern part of Bangladesh. Int J Water Res 1:30-36

10. Armitage PD, Pardo I (1995) Impact assessment of regulation at the reach level using macroinvertebrate information from mesohabitats. Regul Rivers Res Manag 10(2-4):147-158

11. Grill G, Lehner B, Lumsdon AE, MacDonald GK, Zarfl C, Liermann CR (2015) An index-based framework for assessing patterns and trends in river fragmentation and flow regulation by global dams at multiple scales. Environ Res Lett 10(1):015001

12. Bergillos RJ, Rodrıguez-Delgado C, Millares A, Ortega-Sanchez $M$, Losada MA (2016) Impact of river regulation on a mediterranean delta: assessment of managed versus unmanaged scenarios. Water Resour Res 52:5132-5148

13. Prowse TD, Beltaos S, Gardner JT, Gibson JJ, Granger RJ, Leconte R, Peters DL, Pietroniro A, Romolo LA, Toth B (2006) Climate change, flow regulation and land-use effects on the hydrology of the peace-Athabasca-slave system; findings from the northern rivers ecosystem initiative. Environ Monit Assess 113(1-3):167-197

14. Grill G, Dallairea CO, Chouinarda EF, Sindorf N, Lehner B (2014) Development of new indicators to evaluate river fragmentation and flow regulation at large scales: a case study for the Mekong River Basin. Ecol Indic 45(October):148-159

15. (2003) Great lakes climate change hydrologic impact assessment I.J.C. Lake Ontario-St. Lawrence River regulation study. NOAA, Great Lakes Environmental Research Laboratory, Ann Arbor, Michigan

16. Guillen J, Palanques A (1992) Sediment dynamics and hydrodynamics in the lower course of a river highly regulated by dams: the Ebro River. J Int Assoc Sedimentol 39(4):567-579

17. Arp CD, Gooseff MN, Baker MA, Wurtsbaugh W (2006) Surface-water hydrodynamics and regimes of a small mountain stream-lake ecosystem. J Hydrol 329(3-4):500-513

18. King J, Tharme R, Villiers MD (2008) Environmental flow assessments for rivers: manual for the building block methodology (updated edition). WRC report no. TT 354/08

19. Martin J (2013) Hydro-environmental analysis: freshwater environments. CRC Press, Boca Raton

20. Dyson M, Bergkamp G, Scanlon J (2008) Flow-the essentials of environmental flows, 2nd ed. In: International Union for Conservation of Nature (IUCN), Gland, Switzerland

21. King J, Tharme R, Brown C (1999) Definition and implementation of instream flows. World Commission on dams thematic report, Vlaeberg, Cape Town

22. Acreman $M$, Dunbar $M$ (2004) Defning environmental flow requirements-a review. Hydrol Earth Syst Sci 8(5):861-876

23. Korsgaard L (2006) Environmental flows in integrated water resources management: Linking flows, services and values. Technical University of Denmark, Institute of Environment and Resources

24. Richter B, Baumgartner J, Wigington R, Braun D (1997) How much water does a river need? Freshw Biol 37:231-249

25. Henriksen J, Heasley J, Kennen J, Niewsand S (2006) Users' manual for the hydroecological integrity assessment process software. U.S. geological survey, biological resources discipline, open file report 2006-1093

26. Stalnaker C, Lamb B, Henriksen J, Bovee K, Bartholow J (1995) The instream flow incremental methodology: a primer for IFIM. U.S. geological survey biological report 29. USGS, Washington, DC

27. Bovee K, Lamb B, Bartholow J, Stalnaker C, Taylor J, Henriksen J (1998) Stream habitat analysis using the instream flow incremental methodology. U.S. geological survey, biological resources discipline information and technology report USGS/ BRD-1998-0004, USGS, Fort Collins, CO, p 131 
28. Tharme R, King J (1998) Development of the building block methodology for instream flow assessments, and supporting research on the effects of different magnitude flows on river in ecosystems. Water research commission report no. 576/1/98, Water Research Commission, Pretoria

29. Richter B, Warner A, Meyer J, Lutz K (2006) A collaborative and adaptive process for developing environmental flow recommendations. River Res Appl 22:297-318

30. Azadi M (2005) The Halda river, only breeding ground of major carps in Bangladesh: conservation and management. National Fish Fortnight Compendium, Directorate of Fisheries, Ministry of Fisheries and Livestock, Bangladesh

31. Hussain A (2016) Dhak Tribune. 8 Oct 2016. https://www.dhaka tribune.com/bangladesh/2016/10/08/halda-river-declaredecologically-critical-area

32. Fotovatikhah F, Herrera M, Shamshirband S, Chau K-W, Ardabili SF, Piran MJ (2018) Survey of computational intelligence as basis to big flood management: challenges, research directions and future work. Eng Appl Comput Fluid Mech 12(1):411-437

33. Wu CL, Chau KW (2011) Rainfall-runoff modeling using artificial neural network coupled with singular spectrum analysis. J Hydrol 399(3-4):394-409

34. Yaseena ZM, Sulaiman SO, Deo RC, Chau K-W (2019) An enhanced extreme learning machine model for river flow forecasting: state-of-the-art, practical applications in water resource engineering area and future research direction. J Hydrol 569:397-408

35. Taormina R, Chau K-W, Sivakumar B (2015) Neural network river forecasting through baseflow separation and binary-coded swarm optimization. J Hydrol 529(3):1788-1797

36. Ghorbani MA, Kazempour R, Chau K-W, Shamshirband S, Ghazvinei PT (2018) Forecasting pan evaporation with an integrated artificial neural network quantum-behaved particle swarm optimization model: a case study in Talesh, Northern Iran. Eng Appl Comput Fluid Mech 12(1):724-737

37. Moazenzadeh R, Mohammadi B, Shamshirband S, Chau K-W (2018) Coupling a firefly algorithm with support vector regression to predict evaporation in northern Iran. Eng Appl Comput Fluid Mech 12(1):584-597

38. Nash J, Sutcliffe J (1970) River flow forecasting through conceptual models part 1-a discussion of principles. J Hydrol 10(3):282-290

39. Deltares (2018) Delft3D flow, hydro-morphodynamics user manual. Deltares, Delft

40. NRC (2005) The science of instream flows: a review of the Texas instream flow program. Committee on review of methods for establishing instream flows for Texas Rivers. The National Academies Press, Washington, DC

41. Conservancy Nature (2007) Indicators of hydrologic alteration (version 7 user's manual). The Nature Conservancy, Arlington, VA

42. Verma R, Murthy S, Tiwary R (2015) Assessment of environmental flows for various sub-watersheds of Damodar river basin using different hydrological methods. J Waste Resour 5(182):1-6

43. Azadi MA, Alam MA (2013) Ichthyofauna of the River Halda. Bangladesh J Zool 41(2):113-133

Publisher's Note Springer Nature remains neutral with regard to jurisdictional claims in published maps and institutional affiliations. 